\title{
Overview of eutrophication indicators to assess environmental status within the European Marine Strategy Framework Directive
}

João G. Ferreira ${ }^{a{ }^{*} \text {, Jesper H. Andersen }}{ }^{\mathbf{b}}$, Angel Borja ${ }^{c}$, Suzanne B. Bricker ${ }^{\mathbf{d}}$, Jordi Camp ${ }^{\mathbf{e}}$, Margarida Cardoso da Silva ${ }^{f}$, Esther Garcés ${ }^{\mathrm{e}}$, Anna-Stiina Heiskanen ${ }^{\text {, }}$ Christoph Humborg ${ }^{\mathrm{h}}$, Lydia Ignatiades $\mathrm{s}^{\mathrm{i}}$, Christiane Lancelot', Alain Menesguen ${ }^{\mathbf{k}}$, Paul Tett', Nicolas Hoepffner ${ }^{\mathrm{m}}$ and Ulrich Claussen ${ }^{\mathrm{n}}$

\footnotetext{
a Centre for Ocean and Environment, DCEA-FCT, Universidade Nova de Lisboa, Qta da Torre, 2829-516 Monte de Caparica, Portugal

${ }^{\mathrm{b}}$ National Environmental Research Institute, Aarhus University, Frederiksborgvej 399, 4000 Roskilde, Denmark

${ }^{c}$ AZTI-Tecnalia, Marine Research Division, Pasaia, Spain

d NOAA-National Ocean Service, National Centers for Coastal Ocean Science, 1305 East West Highway, Silver Spring, MD 20910, USA

e Departament de Biologia Marina i Oceanografia, Institut de Ciències del Mar, Consejo Superior de Investigaciones Científicas (CSIC), Pg. Marítim de la Barceloneta 37-49, 08003 Barcelona, Spain

${ }^{f}$ LNEC, AV do Brasil 101, 1700-066 Lisboa, Portugal

${ }^{9}$ Finnish Environment Institute, Marine Research Centre, P.O. Box 140, 00251 Helsinki, Finland

${ }^{\mathrm{h}}$ Baltic Nest Institute, Stockholm Resilience Centre, Stockholm University, SE-10691 Sweden

i National Center of Scientific Research, Demokritos, Institute of Biology, Aghia Paraskevi, 15310 Athens, Greece

j Université Libre de Bruxelles, Ecologie des Systèmes Aquatiques, Boulevard du Triomphe CP 221 B-1050, Belgium

k Département ODE(Océanographie et Dynamique des Ecosystèmes) Unité DYNECO(DYNamiques de I'Environnement COtier) Laboratoire EB(Ecologie Benthique) IFREMER/Centre de Brest, B.P. 70 29280, Plouzané, France

' SAMS, Scottish Marine Institute, Oban, Argyll, PA37 1QA, Scotland, UK

m Institute for Environment and Sustainability, Joint Research Centre, Via E. Fermi 2749 I-21027, Ispra VA, Italy

${ }^{n}$ Umweltbundesamt, Federal Environment Agency, Wörlitzer Platz 106844 Dessau-Rosslau, Germany
}

\author{
*: Corresponding author : João G. Ferreira, Tel. : +351212948300 ; Fax: +35121294 2554 \\ Email address : joao@hoomi.com
}

\begin{abstract}
:
In 2009, following approval of the European Marine Strategy Framework Directive (MSFD, 2008/56/EC), the European Commission (EC) created task groups to develop guidance for eleven quality descriptors that form the basis for evaluating ecosystem function. The objective was to provide European countries with practical guidelines for implementing the MSFD, and to produce a Commission Decision that encapsulated key points of the work in a legal framework. This paper presents a review of work carried out by the eutrophication task group, and reports our main findings to the scientific community. On the basis of an operational, management-oriented definition, we discuss the main methodologies that could be used for coastal and marine eutrophication assessment. Emphasis is placed on integrated approaches that account for physico-chemical and biological components, and combine both pelagic and benthic symptoms of eutrophication, in keeping with the holistic nature of the MSFD. We highlight general features that any marine eutrophication model should possess, rather than making specific recommendations. European seas range from highly eutrophic systems such as the Baltic to nutrient-poor environments such as the Aegean Sea. From a
\end{abstract}


physical perspective, marine waters range from high energy environments of the north east Atlantic to the permanent vertical stratification of the Black Sea. This review aimed to encapsulate that variability, recognizing that meaningful guidance should be flexible enough to accommodate the widely differing characteristics of European seas, and that this information is potentially relevant in marine ecosystems worldwide. Given the spatial extent of the MSFD, innovative approaches are required to allow meaningful monitoring and assessment. Consequently, substantial logistic and financial challenges will drive research in areas such as remote sensing of harmful algal blooms, in situ sensor development, and mathematical models. Our review takes into account related legislation, and in particular the EU Water Framework Directive (WFD - 2000/60/EC), which deals with river basins, including estuaries and a narrow coastal strip, in order to examine these issues within the framework of integrated coastal zone management.

\section{Highlights}

- Eutrophication guidance for the EU Marine Strategy Framework Directive (MSFD). Operational, management-oriented definition of eutrophication. Integrated assessment of physico-chemical and biological components. Assessment models combine both pelagic and benthic symptoms of eutrophication. Innovative approaches required for meaningful monitoring and assessment.

Keywords : eutrophication; chlorophyll; dissolved oxygen; harmful algae; Marine; coastal; assessment methods; Europe; marine Strategy Framework Directive; water Framework Directive 


\section{Introduction}

In its original use and etymology, 'eutrophic' meant 'good nourishment', and eutrophication meant the process by which water bodies grew more productive (Thiennemann, 1918; Naumann, 1919). About 50 years ago, however, it became clear that this 'good nourishment' had considerable environmental impacts in fresh water environments such as lakes and reservoirs (e.g. Vollenweider, 1968; Rodhe, 1969; Vollenweider \& Dillon, 1974; Carlson, 1977), and subsequently similar concerns arose for estuarine and coastal systems (e.g. Ketchum, 1969; Ryther \& Dunstan, 1971; Bayley et al., 1978; D'Elia et al., 1986; Lohrenz et al, 1999).

These concerns resulted in political action, translated into specific programmes implemented by conventions such as the Oslo-Paris Convention (OSPAR, 2002), and into legislative instruments such as the Urban Wastewater Treatment Directive (UWWTD - CEC, 1991a) in the European Union and the Clean Water Act in the United States. Other nations also consigned into law measures for assessing and protecting the aquatic environment from eutrophication (see e.g. Xiao et al., 2007; Borja et al., 2008).

The arrival of legislation led to challenges to its implementation, and a need for legal agreement on definitions. Nixon (1995) proposed that eutrophication is "an increase in the rate of supply of organic matter in an ecosystem". Although this definition was appealing to the scientific community, and correctly emphasized that eutrophication is a process rather than a state, from a management perspective it leaves substantial room for interpretation in a court of law.

As a result, by the end of the $20^{\text {th }}$ Century, eutrophication had acquired a scientific and legal meaning, which in Europe was enshrined in (i) several European Directives; (ii) a decision by the European Court of Justice in 2004 (ECJ, 2004); and (iii) OSPAR's 1998 (OSPAR, 1998b) definition: "Eutrophication means the enrichment of water by nutrients causing an accelerated growth of algae and higher forms of plant life to produce an undesirable disturbance to the balance of organisms present in the water and to the quality of the water concerned, and therefore refers to the undesirable effects resulting from anthropogenic enrichment by nutrients ... ."

The fact that the definition came about at least in part through legal requirements attests to some decades of environmental concern, driven by increasing symptoms such as increases in hypoxia, fish kills, and the occurrence of harmful algae (e.g. Boesch, 2002).

In Europe, action was brought about by the contracting parties of OSPAR for the Northeast Atlantic, the Helsinki Convention (HELCOM) for the Baltic Sea, and the Barcelona convention (MEDPOL) for the Mediterranean. On the legal front, first generation instruments such as the UWWTD and Nitrates Directive (CEC, 1991b) were followed over the past decade by far more comprehensive legislation: the Water Framework Directive (WFD - EC, 2000), which addresses all surface waters and groundwater, and the Marine Strategy Framework Directive (MSFD - EC, 2008), which establishes a framework for marine environmental policy up to the $200 \mathrm{~nm}$ limit of the European exclusive economic zone (EEZ: Fig. 1). 
The effort that has been placed into eutrophication assessment and control in Europe over the past thirty years has resulted in : (1) systematic collection of datasets for European regional seas, in order to allow for a robust assessment of state and detection of trends ; (2) development and testing of assessment methods focusing on the particular conditions that exist in marine systems ; (3) construction of numerical models to relate nutrient loading, physical processes and biogeochemical cycles to state (eutrophication status), thus providing decision-makers with appropriate tools to test the outcome of management options ; (4) implementation of management measures that include the reduction of nutrient loading to coastal waters.

The WFD does not explicitly consider eutrophication (Andersen et al, 2006), and refers the word only once in Annex VIII, in the (clearly agricultural) context of nitrates and phosphates, Furthermore, because the directive adopts a "deconstructing structural" approach (Borja et al., 2010), there is no holistic model to analyse eutrophication by taking into account pelagic and benthic components, since the WFD evaluates subsets of these as individual quality elements.

By contrast, the MSFD takes a functional approach to eutrophication, establishing it as one of eleven holistic quality descriptors that together allow for environmental status assessment for European marine waters (Borja et al. 2010; Cardoso et al., 2010). The 11 descriptors are: biological diversity; non-indigenous species introduction; populations of exploited fish and shellfish; marine food webs; human-induced eutrophication; seafloor integrity; alteration of hydrographical conditions; concentrations of contaminants; contaminants in fish and other seafood; marine litter; and introduction of energy and noise.

This contribution reports on the marine eutrophication guidance that was prepared for the European Commission (Ferreira et al., 2010), with the objective of informing the practical aspects of implementing the MSFD in all marine waters of the European Union, and aims to contribute to the state of the art in the following areas: (i) interpretation and definition of eutrophication; (ii) indicators, methods, and assessment; and (iii) spatial, temporal, and policy scales, and monitoring guidelines.

\section{Interpretation and definition of eutrophication}

An operational definition of eutrophication was central to subsequent analysis of methodologies and scale. The approach taken was to review existing definitions in light of the MSFD, considering the following points:

(i) Any definition would need to take into account recent developments in the scientific understanding of eutrophication, and in particular the fact that symptoms follow a well established sequence (e.g. Bricker et al., 2003) and vary in their nature, but share a common origin: land-originated nutrient inputs. Nutrients naturally present in the sea include compounds of silicon ( $\mathrm{Si}$ ) as well as those of nitrogen $(\mathrm{N})$ and phosphorus $(\mathrm{P})$, in concentrations that vary seasonally, as a result of natural marine processes (Costanza, 1992; Mageau, et al., 1995). Eutrophication is the result of import-driven enrichment of the 'pristine' seasonal cycle, increasing the stock of nutrients - primarily $\mathrm{N}$ and/or $\mathrm{P}$ - in a water body and thus allowing a greater annual primary production of organic material and potentially leading to accumulation of algal biomass. The overall conceptual model for eutrophication is illustrated in Fig. 2, but it should be noted that disturbance to 
compartments such as macrobenthos and fish can originate from nutrient-related pressure but also e.g. from bottom trawling, overfishing, disease, etc;

(ii) In dealing with large marine areas, it is important to consider on the one hand the issue of spatial variability, and on the other that not all eutrophication symptoms may be relevant. For example, the loss of seagrasses (Submerged Aquatic Vegetation - SAV) may be of paramount importance in the Danish coast (Krause-Jensen et al., 2005) and parts of the Mediterranean but is inapplicable in deeper environments. Similarly, while it was felt that species shifts, and in particular those that lead to harmful algal blooms (HAB) must be an integral part of any definition, it is important to distinguish operationally between $\mathrm{HAB}$ that are clearly discharge-driven, and those that occur naturally through events such as offshore upwelling relaxation (Anderson \& Garrison, 1997 ; Barale et al., 2008 ; D'Ortenzio and Ribera d'Alcalà, 2009 and Siokou-Frangou et al., 2010);

(iii) At the scale of the MSFD, significant areas are oligotrophic, such as the Eastern Mediterranean (Ignatiades, 1998 ; Ignatiades, 2005 ; D'Ortenzio and Ribera d'Alcalà, 2009 ; Ignatiades et al., 2009 and HELCOM, 2009). Away from the coastal fringe, the issues in such areas are quite different to the case of the southern North Sea (OSPAR, 2008; Claussen et al., 2009) and Baltic Sea (HELCOM, 2009; Andersen et al., 2010; HELCOM, 2010). Since enrichment can occur naturally (Table 1), and can in some systems be a desirable stimulus e.g. to fisheries, management concern should focus on the extent to which anthropogenic nutrients may cause increases in primary production, and/or changes in N:P:Si ratios that shift the balance of primary producers from siliconrequiring diatoms towards non-siliceous algae, including cyanobacteria. Because these shifts may not be harmful in themselves, the main worry concerns 'undesirable disturbance': the potential effects of the increased production, and the direct and indirect changes in the balance of organisms, on ecosystem structure and function and on the ecosystem goods and services used by humans (Krebs, 1988; van de Koppel et al., 2001, 2008). However, such effects do not always follow from nutrient enrichment, and can result from other causes, including climate change, the removal of top predators by fishing, enrichment by allochthonous organic matter, and contamination by harmful substances. A final cause for concern is that these pressures may combine to produce larger effects (e.g. overfishing might exacerbate eutrophication problems). Thus, it is important that MSFD descriptors are not considered in isolation (Borja et al., 2010).

The MSFD eutrophication quality descriptor refers to the adverse effects of eutrophication as including "losses in biodiversity, ecosystem degradation, harmful algae blooms and oxygen deficiency in bottom waters".

Oxygen deficiency can result from the sinking and decomposition of the excess organic matter produced as a result of eutrophication. It can also derive from other causes, including discharges of allochthonous organics and decreases in the ventilation of deep water caused for example by climate change. Ecosystem degradation is understood herein as an undesirable disturbance to the structure, vigor in function, resistance to change and resilience in recovery, of ecosystems, i.e. to ecosystem health (Tett, et al., 2007; Duarte et al., 2009). Because food webs provide part of ecosystem structure, and trophic exchange contributes to ecosystem vigor, there is, clearly, an overlap with the quality descriptor concerning marine food webs. Damage to ecosystem structure can include loss of biodiversity, and changes in the "balance of organisms" (Krause-Jensen et al., 2008; McQuatters-Gollop et al., 2009) certainly implies a shift in relative 
abundances of species' populations. Thus there is an overlap with quality descriptor concerning biological diversity.

Harmful algal bloom (HAB) is a broad term that embraces many phenomena (Anderson \& Garrison, 1997). We will distinguish three types of harmful blooms: (i) those due to toxic algae (e.g. Karenia, Alexandrium, Dinophysis and Pseudonitzschia) that can poison shellfish even at low algal abundance; (ii) potentially toxic algae (e.g. Pseudonitzschia); and (iii) high-biomass blooms (e.g., Phaeocystis, Lepidodinium, Noctiluca) that cause problems mainly because of the high biomass itself. High-biomass blooms are sometimes called "red tides" but may in fact be brown, green or white discolourations of the sea. Some organisms (e.g. Alexandrium) occur in more than one category (i.e. i. toxic and iii. high-biomass). Links between HABs and nutrient enrichment have been much debated. HABs should be treated as part of the undesirable consequences of eutrophication only if their frequency, amplitude, or toxic content increases in correspondence with increased nutrient input. With respect to algal toxins, there is an overlap with quality descriptor concerning contaminants in fish and other seafood.

In order to account for the various aspects described above, the MSFD eutrophication guidance (Ferreira et al., 2010) proposes the definition below as the basis for the descriptor. The steps that led to this definition, together with detailed explanations, are presented in Table 1.

Eutrophication is a process driven by enrichment of water by nutrients, especially compounds of nitrogen and/or phosphorus, leading to: increased growth, primary production and biomass of algae; changes in the balance of organisms; and water quality degradation. The consequences of eutrophication are undesirable if they appreciably degrade ecosystem health and/or the sustainable provision of goods and services.

\section{Indicators, methods, and assessment}

Many methods have been developed in the EU and elsewhere to evaluate and track trends in eutrophication in order to fulfill requirements of legislation designed to monitor and protect coastal water bodies from degradation (see above). The progression of eutrophication symptoms is well described (Fig. 2) and most eutrophication assessment methods recognize that the immediate biological response is increased primary production reflected as increased chlorophyll a $(\mathrm{Chl}$ a) and/or macroalgal abundance (Bricker et al., 2007; Ferreira et al., 2007; Xiao et al., 2007; Borja et al., 2008, in press; OSPAR, 2008; HELCOM, 2009; Nixon, 2009; Tables 1, 2, 3). These are 'direct effects' or 'primary symptoms' and indicate the first stages of eutrophication (Fig. 2). 'Indirect effects' or 'secondary symptoms' such as low dissolved oxygen, losses of SAV, and occurrences of nuisance and toxic blooms (i.e. HAB) indicate more well developed problems (OSPAR, 2002, 2008; Bricker et al., 1999, 2003, 2007, 2008; Claussen et al., 2009; HELCOM, 2009, 2010).

Most eutrophication assessment methods include integration of physico-chemical and biological indicators that provide information at an appropriate level of confidence, in order to form the basis for management decisions (e.g. Borja et al., 2008, in press; Zaldívar et al., 2008; Table 2). Although some methods use only selected water column parameters - i.e. Chl a, dissolved oxygen and nutrients, e.g. TRIX (Vollenweider et al., 1998) and US Environmental Protection Agency National Coastal Assessment (EPA NCA; USEPA, 2008) - others combine additional water column and other indicators such 
as occurrence of $\mathrm{HAB}$, macroalgal abundance and changes in distribution of SAV (Bricker et al., 2003). Many methods include both 'direct' and 'indirect' effects to provide the best possible evaluation of the nutrient-related quality of the water body (see Borja et al., in press).

Selected indicators must show a gradient that reflects the level of human-induced impairment where an increase in nutrient loads leads to increased water quality problems. Ideally, an assessment will provide results showing the level of impairment and the concurrent load and dominant source(s) of nutrients (e.g. Table 2 and Table 3) that have caused observed impairment so that management measures can be targeted for maximum effectiveness. For example, the European Environment Agency Environmental Monitoring and Assessment (EEA- EMMA) 'indicator comparison process' (Royo et al., 2008) concluded that "nutrient concentrations when used jointly with $\mathrm{Chl}$ a are a closer step toward a eutrophication assessment", however, nutrient concentrations may not be useful in all coastal waters. In marine waters this needs further research since eutrophication symptoms are often more clearly related to nutrient load, to susceptibility factors such as mixing and residence time, and to underwater light climate. Although the methods discussed here were developed for transitional and coastal waters they should be considered a starting point for development of assessment methods for waters falling within the jurisdiction of the MSFD (Ferreira et al., 2010).

\subsection{Considerations for Indicator development: Chlorophyll a}

Although many multi-parameter assessment methods have been developed, the indicators that are combined and the specific manner of combination differ among methods (Table 2 and 5). However, $\mathrm{Chl}$ a, used as a measure of phytoplankton biomass, is common to all methods and there is extensive literature on its use as an indicator in inshore and offshore waters (Bricker et al., 1999, 2003, 2005, 2007, 2008; Kowalewska et al., 2004; Zaldívar et al., 2008; Borja et al., 2008, in press; Boyer et al., 2009; Claussen et al., 2009, Garmendia et al. 2009; Carstensen and Henriksen, 2009; Devlin et al., 2007, 2009; HELCOM, 2009). Though all assessment methods include Chl $\mathrm{a}$, the metrics are different and thus the Chl a indicator is a good example of the variability that exists among indicator formulations and highlights important considerations for indicator development. For example, though the thresholds and ranges of $\mathrm{Chl}$ a concentrations for transitional water classification are notably similar among methods, the timeframe and spatial scales of sampling, the statistical measures used to determine representative concentrations (e.g. mean annual, index period mean and/or maximum, $90^{\text {th }}$ percentile; Table 4), the determination of reference conditions and the combination of characteristics for the final status rating are different.

\section{Statistical measures, determination of reference conditions, and indicator formulations}

Equally important to the timing and spatial representativeness of samples are the statistical measures used to determine indicator concentrations, the determination of reference conditions that represent the acceptable/desired concentration and the formulation of the indicator. Again using $\mathrm{Chl}$ a as an example, the US EPA NCA (US EPA 2001, 2005, 2008) and ASSETS (Bricker et al., 1999, 2003) method RCs and concentration ranges are determined from national studies. While they are relevant for 
most estuaries, accommodation (i.e. different scaling) is made for more or less sensitive systems and it is likely that areas within the MSFD framework will need this type of accommodation. The EPA NCA method uses a ratio of good/fair to poor/missing from all sampling stations to determine the final rating. EPA NCA method uses measured concentrations compared to RCs, while the ASSETS method uses the $90^{\text {th }}$ percentile of annual data. The ASSETS method includes the spatial coverage of high concentrations, and the frequency of occurrence of blooms in the formulation to provide a comprehensive picture of $\mathrm{Chl}$ a condition.

The IFREMER (Souchu et al., 2000) method uses the 90th percentile of annual or seasonal $\mathrm{Chl}$ a data which is compared to a fixed scale RC that is determined from studies such as those of the Organization for Economic Cooperation and Development (OECD; Vollenweider et al., 1968) and are consistent with the scales reported for EPA NCA and ASSETS (Table 4).

The TWQI/LWQI (Giordani et al., 2009) method uses non-linear functions to transform annual average $\mathrm{Chl}$ a concentrations from sites representative of the system into a Quality Value (QV) that is then multiplied by a weighting factor e.g. that accounts for the relative contribution of $\mathrm{Chl}$ a to the overall index. The Chl a QV scores, are consistent with the reference condition scales of the EPA NCA, ASSETS and IFREMER.

The HEAT method (Andersen et al., 2010 and HELCOM, 2009), the OSPAR COMPP (Topcu et al., 2009) and WFD determine reference conditions from historical data, empirical modelling or ecological modelling for pristine conditions.

The HEAT method and WFD determined methods use an Ecological Quality Ratio (EQR) approach while for the OSPAR COMPP (Claussen et al., 2009), a Problem Area is indicated if measured $\mathrm{Chl} a$ is greater than the RC $+50 \%$. The WFD RCs were developed during intercalibration exercises and reflect the location of the assessment, e.g. Basque coast (Revilla et al., 2009; European Commission, 2008). The WFD assessments use both $90^{\text {th }}$ percentile and the mean of $\mathrm{Chl}$ a for the vegetative growth period as indicators of phytoplankton biomass (Table 4). The Statistical Trophic Index (STI; Ignatiades, 2005) assesses the trophic status of sea water using seasonal data for $\mathrm{Chl}$ a and for primary production. The data are scaled statistically by the analysis of probabilistic parameters. This analysis estimates the limits of average concentrations in the relationship eutrophic $>$ mesotrophic $>$ oligotrophic for $\mathrm{Chl}$ a, primary production, and physico-chemical parameters by defining thresholds and reference conditions among inshore, offshore, and open ocean waters. Unlike the other methods, the TRIX method does not us reference conditions or scaling for $\mathrm{Chl}$ a individually, having only a scale for the integrated rating with four other indicators (Table 4).

These existing methods provide guidance about the important considerations when developing an indicator. While $\mathrm{Chl}$ a is used here as an example, the same framework with respect to the spatial and temporal sampling and use of indicator characteristics (e.g. concentration, spatial coverage, frequency of occurrence) should be considered in developing other biological and physico-chemical indicators. These methods (Table 2 and Table 4) should also be used to determine how to combine indicators into a comprehensive multi-parameter assessment of eutrophication. 


\subsection{Confidence evaluation}

Finally, the methods that are developed should include an evaluation of the confidence for each indicator and for the overall eutrophication status rating. Given the different spatial scales and timeframes of data that might be used and compared among different water bodies, as well as the different ways to develop RCs, it is highly recommended that the results have an associated level of confidence. At present there are two methods to consider for development of this type of assessment. Bricker et al. (1999, 2007) use the availability and confidence (based on spatial coverage and analytical considerations) of data to determine a Data Confidence and Reliability assessment. The evaluation developed by Andersen et al. (2010) includes a combined evaluation of confidence that includes RCs, deviation from RCs and the actual status of the water body. These methods would be useful as a starting point for development of an evidence-based confidence rating to accompany the eutrophication status rating in marine waters. This is particularly important given the likelihood that assessment methods will be developed differently to address conditions within specific regions.

\subsection{Recommended Indicators for Monitoring and Assessment}

The eutrophication indicators that should be monitored in marine waters can be developed from the list of indicators derived from previous studies (Table 5), though there may be others that are more relevant and SAV may not be appropriate in deeper waters.

To provide a complete picture of eutrophic conditions, other characteristics in addition to Chl a should be included, such as changes in community composition, occurrence of nuisance and potentially toxic species that result from changes in nutrient ratios, and increased duration and frequency of blooms that result from increases in nutrient loads (Table 5).

Most pressures resulting in eutrophication come from coastal areas, producing a strong gradient from coastal to offshore waters; consequently it is recommended that the WFDassess the status in coastal waters using all elements (biological and physicochemical) affected by eutrophication (Table 4). This must then be complemented, within the MSFD, using phytoplankton and physico-chemical (e.g. nutrients, Secchi disc, etc.) indicators in offshore and open marine waters (Borja et al., 2010).

It is fundamental to include nutrient sources and loads (e.g. terrestrial, airborne) so the load can be associated with impairment and successful management measures can be developed from that relationship (Bricker et al., 2007; OSPAR 2008, HELCOM 2009). One potential tool is the indicator of coastal eutrophication potential ICEP indicator (Billen and Garnier, 2007), which estimates the eutrophication potential of nutrient river loads on basis of their N:P:Si ratios. The framework for a monitoring program should also be guided by established assessment procedures, such as the OSPAR Comprehensive Procedure (OSPAR, 2002, 2008; HELCOM 2009, 2010). For example, to maximize efficiency of monitoring as well as resource use a screening process might be used whereby only water bodies showing impairment or risk from anthropogenic nutrient loads in an initial assessment would be the focus of a more intensive monitoring and assessment program. The initial screening should be done periodically to ensure that any creeping eutrophication would be detected. 


\section{Spatial, temporal, and policy scales, and monitoring guidelines}

\subsection{Spatial scale}

5.1.1. Effects of increasing the nutrient load

Eutrophic areas are primarily located near the coast (e.g. Diaz and Rosenberg, 2008), because nutrient enrichment is the first factor promoting eutrophication. Although these are typically sensitive areas receiving anthropogenic nutrient loading, some natural symptoms of eutrophication can also be found in upwelling regions. An increase in nutrient discharge to coastal areas leads to increased phytoplankton biomass during the spring bloom, but also to the emergence of additional episodic blooms during summer and autumn (e.g. Cugier et al., 2005). For European seas, satellite maps compiled from summer data show a very heterogeneous distribution of highly productive areas along the European shores. While the whole shallow south and eastern North Sea, a significant part of the Baltic Sea, and the Black Sea, are highly productive, the Atlantic and Mediterranean exhibit only a strip of high production along the coast. It should, however, be noted that current algorithms for processing remotely sensed sea colour may overestimate chlorophyll in waters containing high levels of coloured dissolved organic matter (e.g. the Baltic) or suspended particulate matter (e.g. the North Sea).

The EUTRISK index (Druon et al., 2004) maps the risk of summertime eutrophication. Extensive risk areas include: (i) Baltic coastal waters with the exception of the northernmost region, the Kattegat and coastal water in the Skagerrak; (ii) the central and southern North Sea and the coastal waters west of Jutland; (iii) the Azov Sea and western coastal belt of the Black Sea; (iv) the northern Adriatic Sea, and the northern French coast of the Bay of Biscay. In the case of the Baltic, these areas largely correspond to those identified by the HELCOM thematic assessment as 'eutrophic', and in northwestern European waters, they largely correspond to those identified by the OSPAR comprehensive procedure as 'problem areas'.

\subsubsection{The role of bathymetry and hydrodynamics}

The risk of eutrophication is linked to the capacity of the marine environment to confine growing algae in the illuminated surface layer. The geographical extent of potentially eutrophic waters along European coasts may vary widely, depending on:

(1) the extent of shallow areas, i.e. with depth $\leq 20 \mathrm{~m}$;

(2) the extent of stratified river plumes, which can create a shallow surface layer separated by a halocline from the bottom layer, whatever its depth. The potential for eutrophication is high where nutrients are introduced into the surface layers of semienclosed water bodies such as fjords or rias that have long periods of water column stratification due to river discharge and/or the deep intrusion of dense coastal water. The risk increases with increasing water residence time;

(3) the presence of long water residence times in enclosed seas leading to blooms triggered to a large degree by internal and external nutrient pools; and 
(4) the occurrence of upwelling phenomena leading to autochthonous nutrient supply and high nutrient concentrations from deep water nutrient pools, which can be of natural or human origin.

A good example of combining features (i) and (ii) is provided by the southern and eastern parts of the North Sea; this shallow (<50 m deep) and tidally mixed region receives, cumulatively from $S W$ to $N E$, the majority of the riverine nutrient loads to the North Sea (Seine, Thames, Scheldt, Rhine, Ems, Weser, Elbe; Lancelot et al., 1987).

\subsection{Temporal scale}

\subsubsection{Effects of changing the nutrient balance}

Except in permanently stratified, deep areas, such as the central Baltic Sea, the acute quantitative symptom of eutrophication, i.e. severe hypoxia, is a seasonal feature, which occurs only after strong primary production episodes, mainly in late spring and in summer, when calm weather and seasonal formation of a pycnocline prevent atmospheric oxygen from being brought to deep water layers.

At the qualitative level, eutrophication may alter the natural succession of species during the year. The terrestrial waterborne loadings on the European coastal shelf have varied during the last century in a nearly independent way for the three main nutrients N, P and silica (Si). Whereas Si remained quasi-constant or slightly declined due to partial trapping by settling freshwater diatoms upstream of dams, P increased until the 1990's, and then decreased due to the polyphosphate ban in detergents and phosphate removal in sewage treatment plants (e.g. Billen et al, 2001; 2005); $\mathrm{N}$ increased continuously during the second half of the $20^{\text {th }}$ century, but began to slightly decrease during the last decade due to implementation of European legislation such as the Nitrates directive (CEC, 1992). The changes in N:P:Si balance have induced some shifts in the phytoplanktonic flora, both in the abundance of diatoms relative to other groups, and in the relative importance of (regional) indicator species. In the Greater North Sea, for instance, undesirable blooms of two haptophytes have been recorded. Phaeocystis globosa, which forms spherical colonies with foam as by-product, invades the coastal strip off France, Belgium, the Netherlands and Germany every spring (April-May; Lancelot, 1995). The toxin-producing Chrysochromulina spp., which blooms between April and August in the Kattegat and Skagerrak (Dahl et al., 2005), was responsible in May-June 1988 for an extensive episode of toxicity decimating farmed fish (Dahl et al., 1991). These haptophytes are known to follow the early-spring diatom bloom (Rousseau et al., 2002; Dahl et al., 2005) when a remaining excess of nitrate allows their rapid growth, even if phosphate conditions are low (Lancelot et al., 1998, Dahl et al., 2005), because both species are mixotrophs, being able to use organic forms of phosphorus (Veldhuis et al., 1991; Paasche, 2002). In the Baltic, the decrease of Si levels and concurrent increase of $\mathrm{N}$ and $\mathrm{P}$ inputs have led to a flagellate dominance in some areas and to elevated production and sedimentation. A similar situation was observed in the NW Black Sea in the mid 1970s where the nearly simultaneous increase of N and P and decrease in Si led to the dominance of Prorocentrum cordatum over diatoms. In the Black Sea, the N:P:Si imbalance was however exacerbated by Si retention in reservoirs in the Danube (Humborg et al; 1997). Presently, however, all three nutrients have decreased for different reasons allowing a better balance in N:P:Si stoichiometry (Yunev et al., 2007). 
Along the Atlantic and English Channel coasts, several harmful species of phytoplankton have been recorded, producing diseases in human consumers of shellfish. Some of them are dinoflagellates, and may have been triggered by summer excess nutrient in the coastal plumes (Guillaud and Ménesguen, 1998).

In the Baltic Sea, the increased magnitude and frequency of cyanobacterial blooms (including toxic species like Nodularia spumigena) has been related to increased nutrient levels (both $\mathrm{N}$ and $\mathrm{P}$ ) during the last decades. Elevated nutrient inputs, maintaining increased phytoplankton spring bloom production and sedimentation, leading to an extension of anoxic bottoms and triggering regeneration of $P$ from sediments, are maintaining a vicious circle where external nutrient loading (both $\mathrm{N}$ and $\mathrm{P}$ ) enhances the occurrence of cyanobacterial blooms in the Baltic.

The coastal waters of the western Aegean Sea (E. Mediterranean) have not been prone to seasonal blooms of the invader species Alexandrium minutum because the local nutritional status did not support its $\mathrm{N}: \mathrm{P}$ ratio requirements and the phytoplankton communities were dominated by diatoms that were strong competitors of this species.

\subsection{Policy scales}

As a result of the WFD, European Member States have delineated coastal water bodies (e.g. Ferreira et al., 2006), however in most cases, since the seaward limit is defined in the directive as "a distance of one nautical mile on the seaward side from the nearest point of the baseline from which the breadth of territorial waters is measured", such water bodies miss the largest part of wide eutrophic plumes. Turbidity in estuarine waters and near the coast is often too high to allow strong primary production, whereas enriched surface waters further offshore can host very productive communities when suspended inorganic particles have settled.

Good Environmental Status (GES) has to be set for areas within the EEZ, based on eutrophication parameters that will be part of the monitoring programmes. Such areal delineation should be based on oceanographic characteristics, such as the Physically Sensitive Area (PSA), the JRC EUTRISK indices (Druon et al., 2004), and the subdivision used by HELCOM and OSPAR.

Some improvement in these indices would probably be gained by using new techniques of revealing the dynamically confined areas in the open coastal ocean (Ménesguen and Gohin, 2006), as well as tracking the far-field impact of national river loadings (Ménesguen et al., 2006) to assess the trans-boundary effects (e.g. OSPAR ICG-EMO group, Anon., 2009). Modelling may provide a new insight into long-range effects which are difficult to measure by field sampling techniques. Enclosed seas such as the Baltic, where eutrophication is impacting almost the whole area, require a regional approach, where delineation of areas and related GES targets are based on evaluation of longterm development and on-going modelling work of the expected impacts of nutrient loading reductions, e.g. as planned by the Baltic Sea Action Plan (Wulff et al., 2007). The next step will be to set clear GES criteria for eutrophication parameters for these areas. Lessons may be learned from the Baltic Sea, where visions and goals have been agreed via the Baltic Sea Action Plan and a process of setting targets has been started, and from a similar process currently being developed by OSPAR. 


\subsection{Monitoring guidelines}

\subsubsection{Spatial and temporal scales}

The spatial and temporal monitoring framework is an important issue in the determination and confidence of final assessment results (Carstensen, 2007; Andersen et al., 2010). Sampling is designed to capture extreme or problem events or time periods; ideally samples would be taken year round to observe both baseline and bloom concentrations. However, when resources are limited sampling is usually restricted and places with strong seasonal variability may be limited to samples from the typical bloom period to try to capture peak concentrations, usually the spring or summertime growing season (or winter sampling in the case of nutrients). In marine areas with less well defined seasonality, sampling on an annual cycle may be more appropriate despite resource considerations and in these cases, remote sensing is suggested as a potential solution to these spatial framework issues (Ferreira et al., 2010).

Alternatively, a sampling design could include consideration of both natural characteristics and the human dimension to divide a water body into management units where morphology as well as appropriate indicators of pressure and state would determine zone boundaries as well as sampling locations and frequencies (Ferreira et al., 2006). The benefit to this approach is that in cases where there is a particularly impacted zone or area, special monitoring and management can be implemented.

The sampling framework is addressed differently by the different assessment methods from a one time per index period sampling (i.e. EPA NCA) to monthly sampling during an annual period (Table 4). In marine regions the identification of temporal trends in $\mathrm{Chl} \mathrm{a}$ concentration is important, but the sampling resolution in time (e.g. once a year for the NE Atlantic) and space (very limited station network in some regions) may make trend analysis difficult (Royo et al., 2008).

The spatial coverage of Monitoring Programmes designed to comply with the MSFD may be divided into (a) a coastal strip where the WFD is also enacted; and (b) a more extended marine area (Fig. 1). In the former, the combination of surveillance, operational and investigative monitoring put in place by Member States for WFD compliance (e.g. Ferreira et al, 2007; Borja et al., 2010) is also appropriate for MSFD compliance with respect to eutrophication assessment. In the design of Monitoring Programmes for open marine water, the strong diversity of EU regional seas must be taken into consideration.

In some cases, such as the Baltic, the whole marine area is bounded by limits of territorial waters, and in others, such as the eastern Mediterranean or NE Atlantic, there are marine areas that are international waters. Nevertheless, most of the offshore areas subject to the MSFD generally show limited eutrophication symptoms (Ærtebjerg et al., 2001; Frid et al., 2003). Indirect eutrophication effects (secondary symptoms) such as hypoxia are not observed, except in the Black Sea where this has been a naturally occurring oceanographic phenomenon for much longer than the time-scale of human influence on water quality (Sorokin, 2002).

Due to the wide extent of eutrophic zones in some coastal parts of the European seas, the sampling effort necessary to reliably assess algal biomass will increase significantly in some countries with respect to WFD requirements. Hence, a systematic use of remote sensing of the surface chlorophyll content and other automated sampling techniques 
such as buoys and gliders is recommended, and should be regularly improved by comparison to ground-truthed samples. This approach, associated with the use of models, has allowed a systematic coverage in time and space of the national WFD water bodies (Gohin et al., 2008). In the case of high biomass HAB, remote sensing of $\mathrm{Chl}$ a will probably pick up the signal, with the caveat that when the bloom is not superficial (e.g. when present in thin layers as in the English Channel), it will be a challenge for satellite detection. Low biomass toxic blooms without significant biomass increase are a particular difficulty. In either case, the development of HAB-specific algorithms is an important research recommendation.

Eutrophication indices based on monitoring and/or modelling must consider temporally appropriate datasets, which may (i) favour seasonal datasets (e.g. the productive period and/or winter nutrients); or (ii) an annual cycle, which may be more adequate for marine areas with less well defined seasonality. In order to detect acute effects, which often pose serious threats to the ecosystem, monitoring and modelling must be temporally adjusted to rapidly developing events, such as the sudden and sharp peaks of oxygen depletion in bottom waters. This requires use of several approaches combining studies onboard research vessels with high-frequency automated sampling onboard of ships-ofopportunity, satellite imagery, models, automatic high frequency buoy recordings, and traditional sampling in marine areas that are impacted or at risk of being impacted by eutrophication. Measured data may provide ocean boundary conditions for the WFD coastal area, and help establish the cause of violation of quality thresholds for some indicators.

As in any regional (and transboundary) framework, EU Member States must determine to what extent data needs are covered by national monitoring programmes, and what aspects of the eutrophication assessment are appropriately covered. Any monitoring programme must include appropriate quality assurance, allowing for appropriate intercalibration and comparative assessment, and should be guided by established programmes, such as the OSPAR Comprehensive Procedure (OSPAR 2002, 2008, 2009). On this basis it will be possible to optimize existing monitoring information, and identify where improvements may be made through targeted/ focused additional monitoring.

\subsubsection{Infrastructure improvements}

A long-term monitoring and research infrastructure is needed, including marine/oceanic observation capabilities that include continuous plankton recorders and long-term fixed stations of data collection for model validation. Maintenance of long-term data series and information is important for prevention of misdiagnosis of new events/changes and will improve interpretation of trends in HAB and facilitate development of management measures.

\section{Conclusions}

The work carried out by this MSFD guidance task group identified a number of research areas where increased effort should be placed in order to improve assessment capabilities and thus the potential success of management measures: 


\subsection{Nutrient inputs}

- Estimates of nutrient loads from terrestrial and atmospheric sources, in relation to transitional/coastal retention, and chemical and biological target indicators;

- Natural background nutrient enrichment (e.g. upwelling, import from pristine/good status rivers) compared to human related sources for determination of unimpacted state, and distinction between naturally productive status and anthropogenically eutrophic status for identification of what can and cannot be managed;

- Contribution of transboundary and transnational supply and/or exchange of nutrients compared to terrestrial and atmospheric sources of nutrients and whether/how these can be managed;

- Climate change impacts on availability of nutrients including transportation (e.g. from new circulation patterns, increased rainfall, changes in upwelling/coastal processes that might lead to new or enhanced sources), and transformation of nutrients and organic matter;

- Distinction between climate change and anthropogenic impacts and how best to manage these;

- Relationships between indicators/parameters and proxies for nutrient loading pressures (e.g. change in nutrient concentrations where this can be demonstrated to be an effective proxy) in order to set ecoregion and/or habitatspecific targets for GES.

\subsection{Primary production and algal biomass regulation}

- The relationship among nutrient concentrations, chlorophyll, and primary production, and whether when used jointly they are useful and should be pursued as part of eutrophication assessment, given the stronger linkage of symptoms to nutrient loading, underwater light climate and susceptibility (e.g. mixing and residence time);

- Nutrient regulation and stoichiometry of algal biomass (i.e. phytoplankton and macroalgae) production including nutrient related selection of dominant species, functional groups, and algal community structure;

- New development of phytoplankton assessment tools that account for shifts in species composition and frequency of blooms in the status assessment scoring;

- Relationship between nutrient enrichment and shifts in structure and functioning of the planktonic food web;

- Development of monitoring tools that account for rapid changes in algal communities, allowing detection of bloom peaks (e.g. continuous measurements, ships-of-opportunity, remote sensing tools, algorithm development, etc.); 
- Effect of top-down control (e.g. shellfish filtration, zooplankton grazing) and other food-web interactions (viral infections, parasitism, including the role of mixotrophy (ability to use organic sources of $\mathrm{N}$ and $\mathrm{P}$ ) etc) in regulation of algal biomass and transmitted/ amplified effects.

\subsection{Harmful Algal Blooms}

- Identification and understanding of the link between HABs and land-based nutrient inputs;

- Identification of the role of mechanisms such as upwelling relaxation events, cyst formation etc in $\mathrm{HAB}$ formation, and the extent to which these events are manageable

\subsection{Value, resilience and recovery of marine ecosystems}

- Marine submerged vegetation is valuable for maintenance of biodiversity as it forms habitat for many organisms (invertebrates, fish juveniles, etc.). Research is needed on evaluation of eutrophication impacts including the optimal extent and status of these communities for supporting viable and diverse communities; valuation of goods and services provided by such communities and development of tools for marine spatial planning and management of marine protected areas with respect to eutrophication are also an important area for research;

- Identification of factors that govern the occurrence and extension of the hypoxic/ anoxic events as well as the impacts of such events on resilience and recovery of benthic communities. There is a need to distinguish between the natural range and increases in spatial extent of anoxic sediments and bottom waters due to anthropogenic organic loading;

- Determination of the resilience of marine ecosystems for identification of critical nutrient loading thresholds beyond which the whole system shifts to an alternative steady state. This includes research exploring potential recovery pathways from eutrophic to non-eutrophic states. This is not well established because system functioning and components may have changed and the recovery pathway and restoration outcome may not be identical to rate of deterioration or the original status before impairment;

\subsection{Selection of criteria and indicators for eutrophication assessment by the MSFD}

The efforts of the working group on the MSFD qualitative descriptor of human-induced eutrophication resulted in the selection by the European Commission (EC; 2010) of three different aspects (nutrient levels; direct and indirect effects of nutrient enrichment) and eight indicators, which can potentially be used in the environmental status assessment within the MSFD:

(1) for nutrient levels: nutrient concentration in the water column; nutrient ratios (silica, nitrogen and phosphorus), 
(2) for direct effects of nutrient enrichment: chlorophyll concentration in the water column; water transparency related to increase in suspended algae; abundance of opportunistic macroalgae; and species shift in floristic composition, such as diatom to flagellate ratio, benthic to pelagic shifts, as well as bloom events of nuisance/toxic algal blooms caused by human activities;

(3) for indirect effects of nutrient enrichment: abundance of perennial seaweeds and seagrasses adversely impacted by decrease in water transparency; dissolved oxygen changes due to increased organic matter decompostion and size of the area concerned.

The assessment must consider relevant temporal scales and the relationship to nutrient loads from rivers in the catchment area. The EC decision encourages the use of previous information and knowledge gathered and approaches developed in the framework of regional sea conventions, such as those described here, as a starting point.

\section{Acknowledgements}

The authors are grateful to the European Commission, International Council for the Exploration of the Sea, and the EU Joint Research Centre for the opportunity to develop this work. We would particularly like to thank Ana Cristina Cardoso (JRC), Carlos Berrozpe-Garcia and Sif Johansson and (EC), and Claus Hagebro (ICES).

\section{References}

Andersen, J.H., Axe, P., Backer, H., Carstensen, J., Claussen, U., Fleming-Lehtinen, V., Järvinen, M., Kaartokallio, H., Knuuttila, S., Korpinen, S., Laamanen, M., LysiakPastuszak, E., Martin, G., Møhlenberg, F., Murray, C., Nausch, G., Norkko, A., Villnäs, A., 2010. Getting the measure of eutrophication in the Baltic Sea: towards improved assessment principles and methods. Biogeochemistry. doi:10.1007/s10533-010-9508-4.

Andersen, J.H., Schlüter, L., Ærtebjerg, G., 2006. Coastal eutrophication: recent developments in definitions and implications for monitoring strategies. Journal of Plankton Research 28 (7), 621e628.

Anderson, D.M., Garrison, D.L., 1997. The ecology and oceanography of harmful algal blooms: preface. Limnology and Oceanography 42, 1007e1009.

Barale, V., Jaquet, J.M., Ndiaye, M., 2008. Algal blooming patterns and anomalies in the Mediterranean Sea as derived from the SeaWiFS data set (1998e2003). Remote Sensing of Environment 112, 3300e3313.

Bayley, S., Stotts, V.D., Springer, P.F., Steenis, J., 1978. Changes in submerged aquatic macrophyte populations at the head of Chesapeake Bay, 1958e1975. Estuaries $1,73 \mathrm{e} 84$. 
Billen, G., Garnier, J., 2007. River basin nutrient delivery to the coastal sea: assessing its potential to sustain new production of non-siliceous algae. Marine Chemistry $106,148 \mathrm{e} 160$.

Billen, G., Garnier, J., Ficht, A., Cun, C., 2001. Modeling the response of water quality in the Seine river estuary to human activity in its watershed over the last 50 years. Estuaries 24 (6B), 977e993.

Billen, G., Garnier, J., Rousseau, V., 2005. Nutrient fluxes and water quality in the drainage network of the Scheldt basin over the last 50 years. Hydrobiologia 540, $47 e 67$.

Boesch, D.F., 2002. Challenges and opportunities for science in reducing nutrient overenrichment of coastal ecosystems. Estuaries 25, 744e758.

Borja, A., Basset, A., Bricker, S., Dauvin, J.-C., Elliott, M., Harrison, T., Marques, J.C., Weisberg, S., West, R., 2012. Classifying ecological quality and integrity of estuaries. In: Wolanski, E., McLusky, D. (Eds.), Chapter 1.9 within the 'Treatise on Estuarine and Coastal Science'. Elsevier.

Borja, A., Bricker, S.B., Dauer, D.M., Demetriades, N.T., Ferreira, J.G., Forbes, A.T., Hutchings, P., Jia, X., Kenchington, R., Marques, J.C., Zhu, C.B., 2008. Overview of integrative tools and methods in assessing ecological integrity in estuarine and coastal systems worldwide. Marine Pollution Bulletin 56, $1519 \mathrm{e} 1537$.

Borja, Á, Elliott, M., Carstensen, J., Heiskanen, A.-S., van de Bund, W., 2010. Marine management - Towards an integrated implementation of the European Marine Strategy Framework and the Water Framework Directives. Marine Pollution Bulletin 60, 2175e2186.

Boyer, J.N., Kelble, C.R., Ortner, P.B., Rudnick, D.T., 2009. Phytoplankton bloom status: chlorophyll a biomass as an indicator of water quality condition in the southern estuaries of Florida, USA. Ecological Indicators 9, S56eS67.

Bricker, S.B., Longstaff, B., Dennison,W., Jones, A., Boicourt, K., Wicks, C.,Woerner, J., 2007. Effects of Nutrient Enrichment in the Nation's Estuaries: a Decade of Change, National Estuarine Eutrophication Assessment Update. NOAA Coastal Ocean Program Decision Analysis Series No. 26. National Centers for Coastal Ocean Science, Silver Spring, MD. http://ccma.nos.noaa.gov/news/feature/ Eutroupdate.html, pp. 322.

Bricker, S.B., Longstaff, B., Dennison,W., Jones, A., Boicourt, K., Wicks, C.,Woerner, J., 2008. Effects of nutrient enrichment in the Nation's estuaries: a decade of change. Harmful Algae 8, 21 e32.

Bricker, S.B., Clement, C.G., Pirhalla, D.E., Orlando, S.P., Farrow, D.R.G., 1999. National Estuarine Eutrophication Assessment. Effects of Nutrient Enrichment in the Nation's Estuaries. NOAA, National Ocean Service, Special Projects Office and National Centers for Coastal Ocean Science, Silver Spring. 
Bricker, S.B., Ferreira, J.G., Simas, T., 2003. An integrated methodology for assessment of estuarine trophic status. Ecological Modelling 169, 39e60.

Bricker, S.B., S.V. Smith, J.G. Ferreira, A.M. Nobre, E. Dettmann, J. Latimer. 2005. Assessment of eutrophication: A comparison of methods applied to Barnegat Bay. Estuarine Research Federation 2005, Session SYM-06: Managing River Basins and Estuaries: an International Assessment of Approaches and Progress. http://www.eutro.org/presentations/BarnegatERF2005SYM-06final.pdf

Cardoso, A.C., Cochrane, S., Doemer, H., Ferreira, J.G., Galgani, F., Hagebro, C., Hanke, G., Hoepffner, N., Keizer, P.D., Law, R., Olenin, S., Piet, G.J., Rice, J., Rogers, S.I., Swartenbroux, F., Tasker, M.L., van de Bund, W., 2010. Scientific Support to the European Commission on the Marine Strategy Framework Directive. Management Group Report. EUR 24336 EN e Joint Research Centre. Office for Official Publications of the European Communities, Luxembourg. 57 p..

Carlson, R., 1977. A trophic state index for lakes. Limnology and Oceanography 22, $361 \mathrm{e} 369$.

Carstensen, J., 2007. Statistical principles for ecological status classification ofWater Framework Directive monitoring data. Marine Pollution Bulletin 55, 3e15.

Carstensen, J., Henriksen, P., 2009. Phytoplankton biomass response to nitrogen inputs: a method for WFD boundary setting applied to Danish coastal waters. Hydrobiologia 633, 137e149.

Claussen, U., Zevenboom, W., Brockmann, U., Topcu, D., Bot, P., 2009. Assessment of the eutrophication status of transitional, coastal and marine waters within OSPAR. Hydrobiologia 629, 49e58.

Cloern, J.E., 2001. Our evolving conceptual model of the coastal eutrophication problem. Marine Ecology Progress Series 201, $223 e 253$.

Commission of the European Communities, 1991a. Urban Wastewater Treatment Directive, 91/271/EEC.

Commission of the European Communities, 1991b. Nitrates Directive, 91/676/EEC.

Cooper, S.R., Brush, G.S., 1991. Long-Term history of Chesapeake Bay anoxia. Science 254, 992e996.

Costanza, R., 1992. Towards an Operational Definition of Health. Ecosystem Health New Goals for Environmental Management. Costanza, R., Norton, B \& Haskell, B.D. Inland Press, Washington D.C. 239e256.

Cugier, P., Billen, G., Guillaud, J.F., Garnier, J., Ménesguen, A., 2005. Modelling the eutrophication of the Seine Bight (France) under historical, present and future riverine nutrient loading. Journal of Hydrology, special issue on nutrient mobility within river basins. Journal of Hydrology 304, 381e396. 
D'Elia, C.F., Sanders, J.G., Boynton, W.R., 1986. Nutrient enrichment studies in a coastal plain estuary: phytoplankton growth in large-scale, continuous cultures. Canadian Journal of Fisheries and Aquatic Sciences 43, $397 e 406$.

Dahl, E., Bagoien, E., Edvardsen, B., Stenseth, N.C., 2005. The dynamics of Chrysochromulina species in the Skagerrak in relation to environmental conditions. Journal of Sea Research 54 (1), $15 e 24$.

Devlin, M., Bricker, S., Painting, S., 2011. Comparison of five methods for assessing impacts of nutrient enrichment using estuarine case studies. Biogeochemistry. doi:10.1007/s10533-011-9588-9.

Devlin, M., Barry, J., Painting, S., Best, M., 2009. Extending the phytoplankton tool kit for the UKWater Framework Directive: indicators of phytoplankton community structure. Hydrobiologia 633, 151 e168.

Devlin, M., Best, M., Coates, D., Bresnan, E., O’Boyle, S., Park, R., Silke, J., Cusack, C., Skeats, J., 2007. Establishing boundary classes for the classification of UK marine waters using phytoplankton communities. Marine Pollution Bulletin 55, $91 \mathrm{e} 103$.

Diaz, R., Rosenberg, R., 2008. Spreading dead zones and consequences for marine ecosystems. Science 321, $926 e 929$.

D'Ortenzio, F., Ribera d'Alcalà, M., 2009. On the trophic regimes of the Mediterranean Sea: a satellite analysis. Biogeosciences Discuss 6, 11187 e11293.

Druon, J.-N., Schrimpf, W., Dobricic, S., Stips, A., 2004. Comparative assessment of large-scale marine eutrophication: North Sea area and Adriatic Sea as case studies. Marine Ecology Progress Series 272, $1 \mathrm{e} 23$.

Duarte, C., Conley, D., Carstensen, J., Sánchez-Camacho, M., 2009. Return to Neverland: Shifting baselines affect eutrophication restoration targets. Estuaries and Coasts 32, $29 \mathrm{e} 36$.

Ærtebjerg, G., Carstensen, J., Dahl, K., Hansen, J., Nygaard, K., Rygg, B., Sørensen, K., Severinsen, G., Casartelli, S., Schrimpf, W., Schiller, C., Druon, J.N., 2001. Eutrophication in Europe's Coastal Waters, 7. European Environment Agency, Copenhagen. Topic Report115.

ECJ (2004). Commission of the European Communities v French Republic. Judgement of the European Court of Justice (2nd chamber) on 23 September 2004, in case C 280/02, concerning: Failure of a Member State to fulfil obligations - Directive 91/271/EEC - Urban waste water treatment - Article 5(1) and (2) and Annex IIFailure to identify sensitive areas - Meaning of "eutrophication" - Failure to implement more stringent treatment of discharges into sensitive areas.

European Commission, 2000. Directive 2000/60/EC of the European Parliament and of the Council of 23 October 2000 establishing a framework for Community actions in the field of water policy. Official Journal of the European Communities L327, 1. 22.12.2000. 
European Commission, 2008. Directive 2008/56/EC of the European Parliament and of the Council of 17 June 2008 establishing a framework for Community actions in the field of marine environmental policy (Marine Strategy Framework Directive). Official Journal of the European Communities L164/19 25.06.2008.

European Commission, 2010. Commission Decision of 1 September 2010 on criteria and methodological standards on good environmental status of marine waters (notified under document C(2010) 5956)(2010/477/EU)). Official Journal of the European Union L232, 12e24.

Ferreira, J.G., Nobre, A.M., Simas, T.C., Silva, M.C., Newton, A., Bricker, S.B.,Wolff,W.J., Stacey, P.E., Sequeira, A., 2006. A methodology for defining homogeneous water bodies in estuaries e Application to the transitional systems of the EU Water Framework Directive. Estuarine Coastal and Shelf Science 66, $468 \mathrm{e} 482$.

Ferreira, J.G., Bricker, S.B., Simas, T.C., 2007a. Application and sensitivity testing of an eutrophication assessment method on coastal systems in the United States and European Union. Journal of Environmental Management 82 (4), 433e445.

Ferreira, J.G., Vale, C., Soares, C.V., Salas, F., Stacey, P.E., Bricker, S.B., Silva, M.C., Marques, J.C., 2007b. Monitoring of coastal and transitional waters under the EUWater Framework Directive. Environmental Monitoring and Assessment 135 (1e3), $195 \mathrm{e} 216$.

Ferreira, J.G., Andersen, J.H., Borja, A., Bricker, S.B., Camp, J., Cardoso da Silva, M., Garcés, E., Heiskanen, A.S., Humborg, C., Ignatiades, L., Lancelot, C., Menesguen, A., Tett, P., Hoepffner, N., Claussen, U., 2010. Marine Strategy Framework Directive e Task Group 5 Report Eutrophication. EUR 24338 EN e Joint Research Centre. Office for Official Publications of the European Communities, Luxembourg, pp. 49.

Frid, C., Hammer, C., Law, R., Loeng, H., Pawlak, J.F., Reid, P.C., Tasker, M., 2003. Environmental Status of the European Seas. ICES, pp. 75.

Garmendia, M., Revilla, M., Bald, J., Franco, J., Laza-Martínez, A., Orive, E., Seoane, S., Valencia, V., Borja, Á., 2011. Phytoplankton communities and biomass size structure (fractionated chlorophyll "a"), along trophic gradients of the Basque coast (northern Spain). Biogeochemistry. doi:10.1007/s10533-010-9445-2.

Gelabert, E.R., Emblow, C., Andersen, J.H., 2008. EEA Follow-up to the 'indicator convergence' process started under the EMMA Working Group. Indicator Comparison in 2008 and 'next steps'. European Environment Agency. http:// circa.europa.eu/Public/irc/env/marine/library?!1/4/archive/workingsgroups/europea nsmarinesmonitori/indicator_comparison/1_concept_paper/revised_031008doc/_ EN_1.0_\& $1 \frac{1}{1} / 4$.

Giordani, G., Zaldivar, J.M., Viaroli, P., 2009. Simple tools for assessing water quality and trophic status in transitional water ecosystems. Ecological Indicators 9, 982e991. 
Gohin, F., Saulquin, B., Oger-Jeanneret, H., Lozac'h, L., Lampert, L., Lefebvre, A., Riou, P., Bruchon, F., 2008. Towards a better assessment of the ecological status of coastal waters using satellite-derived chlorophyll-a concentrations. Remote Sensing of Environment 112, 3329e3340.

Guillaud, J.F., Ménesguen, A., 1998. Modélisation sur vingt ans (1976-1995) de la production phytoplanctonique en Baie de Seine (France). Oceanologica Acta 21 (6), 887e906.

HELCOM 2007. HELCOM Baltic Sea Action Plan. Helsinki Commission, Helsinki, Finland. 103 pp. http://www.helcom.fi/BSAP/

HELCOM, 2009. Eutrophication in the Baltic Sea e An integrated thematic assessment of the effects of nutrient enrichment and eutrophication in the Baltic Sea region. Baltic Sea Environment Proceedings No. 115A.

HELCOM, 2010. Ecosystem Health of the Baltic Sea 2003e2007: HELCOM Initial Holistic Assessment. Baltic Sea Environment Proceedings No. 122.

Humborg, C., Ittekkot, V., Cociasu, A., von Bodungen, B., 1997. Effect of Danube River dam on Black Sea biogeochemistry and ecosystem structure. Nature 386, $385 \mathrm{e} 388$.

Ignatiades, L., 1998. The production and optical status of the oligotrophic waters of the Southern Aegean Sea, Eastern Mediterranean. Journal of Plankton Research 20, $987 e 995$.

Ignatiades, L., 2005. Scaling the trophic status of the Aegean Sea, eastern Mediterranean. Journal of Sea Research 54, 51e57.

Ignatiades, L., Gotsis-Skretas, O., Metaxatos, A., 2007. Field and culture studies on the ecophysiology of the toxic dinoflagellate Alexandrium minutum (Halim) present in Greek coastal waters. Harmful Algae 6, $153 e 165$.

Ignatiades, L., Gotsis-Skretas, O., Pagou, K., Krasakopoulou, E., 2009. Diversification of phytoplankton community structure and related parameters along a large eastwest transect of the Mediterranean Sea. Journal of Plankton Research 31, $441 \mathrm{e} 448$.

Ketchum, B.H., 1969. In: Rohlich, G.A. (Ed.), Eutrophication of Estuaries. National Academy of Sciences, Washington, DC, pp. $50 \mathrm{e} 64$.

Kowalewska, G.,Wawrzyniak-Wydrowska, B., Szymczak-Zyla, M., 2004. Chlorophyll a and its derivatives in sediments of the Odra estuary as a measure of its eutrophication. Marine Pollution Bulletin 49, $148 \mathrm{e} 153$.

Krause-Jensen, D., Greve, T.M., Nielsen, K., 2005. Eelgrass as a bioindicator under the European Water Framework Directive. Water Resources Management 19, $63 e 75$.

Krebs, C.J., 1988. The Message of Ecology. Harper \& Row, New York. 
Lancelot, C., 1995. The mucilage phenomenon in the continental coastal waters of the North Sea. Science of the Total Environment 165, 83e112.

Lancelot, C., Keller, M., Rousseau, V., Smith Jr.,W.O., Mathot, S., 1998. Autoecology of the marine haptophyte Phaeocystis sp. In: Anderson, D.A., Cembella, A.M., Hallegraef, G. (Eds.), NATO Advanced Workshop on the Physiological Ecology of Harmful Algal Blooms. NATO-ASI Series. Series G: Ecological Science, 41, pp. $209 \mathrm{e} 224$.

Li, Y., He, R., McGillicuddy Jr., D.J., Anderson, D.M., Keafer, B.A., 2009. Investigation of the 2006 Alexandrium fundyense bloom in the Gulf of Maine: in-situ observations and numerical modeling. Continental Shelf Research 29, $2069 \mathrm{e} 2082$.

Lohrenz, S.E., Fahnenstiel, G.L., Redalje, D.G., Lang, G.A., Dagg, M.J., Whitledge, T.E., Dortch, Q., 1999. Nutrients, irradiance, and mixing as factors regulating primary production in coastal waters impacted by the Mississippi River plume. Continental Shelf Research 19, $1113 e 1141$.

Mageau, M.T., Costanza, R., Ulanowicz, R.E., 1995. The development and initial testing of a quantitative assessment of ecosystem health. Ecosystem Health 1, $201 e 213$.

McGillicuddy Jr., D.J., Anderson, D.M., Lynch, D.R., Townsend, D.W., 2005. Mechanisms regulating large-scale seasonal fluctuations in Alexandrium fundyense populations in the Gulf of Maine: results from a physicalebiological model. Deep-Sea Research II 52, 2698 e2714.

McQuatters-Gollop, A., Gilbert, A.J., et al., 2009. How well do ecosystem indicators communicate the effects of anthropogenic eutrophication? Estuarine, Coastal and Shelf Science $82(4), 583 e 596$.

Ménesguen, A., Gohin, F., 2006. Observation and modelling of natural retention structures in the English Channel. Journal of Marine Systems 63 (3e4), 244e256.

Mississippi River/Gulf of MexicoWatershed Nutrient Task Force, 2008. Gulf Hypoxia Action Plan 2008 for Reducing, Mitigating, and Controlling Hypoxia in the Northern Gulf of Mexico and Improving Water Quality in the Mississippi River Basin. http://www.epa.gov/owow_keep/msbasin/pdf/ghap2008_update082608. pdf Washington, DC.

Naumann, E., 1919. Några synpunkter angående limnoplanktons ökologi med särskild hänsyn till fytoplankton. Svensk Botanisk Tidskrift 13, $129 \mathrm{e} 163$.

Nixon, S., 2009. Eutrophication and the macroscope. Hydrobiologia 629, 5e19.

Nixon, S.W., 1995. Coastal marine eutrophication: a definition, social causes, and future concerns. Ophelia 41, 199e219. 
Oslo Paris Convention for the Protection of the North Sea OSPAR, 2002. Common Assessment Criteria, Their Assessment Levels and Area Classification within the Comprehensive Procedure of the Common Procedure. OSPAR Commission for the protection of the marine environment of the North-East Atlantic. http:// www.ospar.org/eng/html/welcome.html.

OSPAR, 2008. Second OSPAR Integrated Report on the Eutrophication Status of the OSPAR Maritime Area, 2008-372. OSPAR publication, pp. 107.

OSPAR, 2009. Transboundary Nutrient Transport. OSPAR Workshop on Eutrophication Modelling (Transboundary Nutrient Transport), Draft workshop report. Eutrophication Committee (EUC), London, 1e4 Dezember 2009, EUC(2) 09/4/1Rev.1 and Add.1. http://www.cefas.co.uk/publications/miscellaneouspublications/ proceedings-from-ospar-intersessional-correspondence-groupon- eutrophicationmodelling-(icg-emo)-(eutmod-2).aspx.

Paasche, E., 2002. A review of the coccolithophorid Emiliania huxleyi (Prymnesiophyceae), with particular reference to growth, coccolith formation, and calcification-photosynthesis interactions. Phycologia 40, 503e529.

Revilla, M., Franco, J., Bald, J., Laza, A., Seoane, S., Valencia, V., 2009. Assessment of the phytoplankton ecological status in the Basque coast (northern Spain) according to the European Water Framework Directive. Journal of Sea Research $61,60 \mathrm{e} 67$.

Rodhe, W., 1969. Crystallization of eutrophication concepts in northern Europe. In: Rohlich, G.A. (Ed.), Eutrophication: Causes, Consequences, Correctives. National Academy of Sciences, Washington, DC, pp. 50e64.

Rousseau, V., Leynaert, A., Daoud, N., Lancelot, C., 2002. Diatom succession, silicification and silicic acid availability in Belgian coastal waters (Southern North Sea). Marine Ecology Progress Series 236, 61e73.

Ryther, J.H., Dunstan, W.M., 1971. Nitrogen, phosphorus, and eutrophication in the coastal marine environment. Science 171, $1008 \mathrm{e} 1013$.

Siokou-Frangou, I., Christaki, U., Mazzocchi, M.G., Montresor, M., Ribera d'Alcalá, M., Vaqué, D., Zingone, A., 2010. Plankton in the open Mediterranean Sea: a review. Biogeosciences Discussion 6, 11187e11293.

Sorokin, Y.I., 2002. The Black Sea Ecology and Oceanography. Backhuys Publishers, Leiden, Netherlands.

Souchu, P., Ximenes, M.C., Lauret, M., Vaquer, A., Dutrieux, E., 2000. Mise à jour d'indicateurs du niveau d'eutrophisation des milieux lagunaires méditerranéens, août 2000. Ifremer-Créocean-Université Montpellier II, p. 412.

Stumpf, R.P., Tomlinson, M.C., Calkins, J.A., Kirkpatrick, B., Fisher, K., Nierenberg, K., Currier, R., Wynne, T.T., 2009. Skill assessment for an operational algal bloom forecast system. Journal of Marine Systems 76, $151 \mathrm{e} 161$. 
Stumpf, R.P., Culver, M.E., Tester, P.A., Tomlinson, M., Kirkpatrick, G.J., Pederson, B.A., Truby, E., Ransibrahmanakul, V., Soracco, M., 2003. Monitoring Karenia brevis blooms in the Gulf of Mexico using satellite ocean color imagery and other data. Harmful Algae 2, 147e160.

Tett, P., Gowen, R., Mills, D., Fernandes, T., Gilpin, L., Huxham, M., Kennington, K., Read, P., Service, M., Wilkinson, M., Malcolm, S., 2007. Defining and detecting undesirable disturbance in the context of eutrophication. Marine Pollution Bulletin $53,282 e 297$.

Topcu, D., Brockmann, U., Claussen, U., 2009. Relationship between eutrophication reference conditions and boundary settings considering OSPAR recommendations and the Water Framework Directive - examples from the German Bight. Hydrobiologia 629 (1), 91e106.

Thiennemann, A., 1918. Untersuchungen über die Beziehungen zwischen dem Sauerstoffgehalt des Wassers und der Zusammensetzung der Fauna in norddeutschen Seen. Archiv für Hydrobiologie 12, 1 e65.

United States Clean Water Act (PL 92-500), 1972. Public Law 92e500.

U.S. Environmental Protection Agency (USEPA), 1991. Guidance for Water QualityBased Decisions The TMDL Process. Document Number EPA 440/4-91-001. Washington, D.C.

United States Environmental Protection Agency (USEPA), 2001. Environmental Monitoring and Assessment Program (EMAP): National Coastal Assessment Quality Assurance Project Plan 2001-2004. United States Environmental Protection Agency, Office of Research and Development, National Health and Environmental Effects Research Laboratory, Gulf Ecology Division, Gulf Breeze, FL. EPA/620/R-01/002. http://www.epa.gov/emap/nca/html/docs/c2_qapp.pdf

United States Environmental Protection Agency (USEPA), 2008. EPA's 2008 Report on the Environment. National Center for Environmental Assessment, Washington, DC; EPA/600/R-07/045F. http://www.epa.gov/roe, http://cfpub.epa.gov/ ncea/cfm/recordisplay.cfm?deid11/4190806.

United States Environmental Protection Agency (USEPA), 2005. National Coastal Condition Report II. United States Environmental Protection Agency. EPA- 620/ R-03/002. Office of Research and Development, Office of Water, Washington, DC. http://www.epa.gov/owow/oceans/nccr2/.

Vahtera, E., Conley, D.J., Gustafsson, B., Kouse, H., Pitkänen, H., Savchuk, O.P., Tamminen, T., Viitasalo, M., Voss, M., Wasmund, N., Wulf, F., 2007. Internal ecosystem feedbacks enhance nitrogen-fixing Cyanobacteria blooms and complicate management in the Baltic sea. AMBIO:A journal of the Human Environment 36 (2e3), 186e194.

Van De Koppel, J., Herman, P.M.J., Thoolen, P., Heip, C.H.R., 2001. Do alternate stable states occur in natural ecosystems? Evidence from a tidal flat. Ecology 82, $3449 \mathrm{e} 3461$. 
Van de Koppel, J., Tett, P., Naqvi, W., Oguz, T., Perillo, G.M.E., Rabalais, N., d'Alcala, M.R., Jilan, S., Zhang, J., 2008. Chapter 3: Threshold effects in semienclosed marine ecosystems. Watersheds, Bays and Bounded Seas: The Science and Management of Semi-Enclosed Marine Systems, Edward R. Urban, J., Sundby, B., Malanotte-Rizzoli, P. \& Melillo, J.M. Island Press, Washington DC. 31e47.

Veldhuis, M.J.W., Colijn, F., Admiraal, W., 1991. Phosphate utilization in Phaeocystis pouchetii (Haptophyceae). Marine Ecology Progress Series 12 (1), $53 e 62$.

Vollenweider, R.A., Dillon, P.J., 1974. The Application of the Phosphorus Loading Concept to Eutrophication Research. NRCC No. 13690. NRC, Canada.

Vollenweider, R.A., Giovanardi, F., Montanari, G., Rinaldi, A., 1998. Characterization of the trophic conditions of marine coastal waters with special reference to the NW Adriatic Sea: proposal for a trophic scale, turbidity and generalized water quality index. Environmetrics 9, 329e357.

Vollenweider, R.A., 1968. The Scientific Basis for Lake and Stream Eutrophication with Particular Reference to Phosphorus and Nitrogen as Eutrophication Factors. Technical Report DAS/DS1/68.27. Organization for Economic Cooperation and Development, Paris, France.

Wulff, F., Savchuk, O.P., Sokolov, A., Humborg, C., Mörth, C.-M., 2007. Management options and effects on a marine ecosystem: assessing the future of the Baltic. AMBIO 36 (2), 243e249.

Wynne, T.T., Stumpf, R.P., Tomlinson, M.C., Dyble, J., 2010. Characterizing a cyanobacterial bloom in western Lake Erie using satellite imagery and meteorological data. Limnol. Oceanogr. 55 (5), 2025e2036.

Wynne, T., Stumpf, R., Tomlinson, M., Schwab, D., Watabayashi, G., Christensen, J. Estimating cyanobacterial bloom transport by coupling remotely sensed imagery and a hydrodynamic model. Ecological Applications, in press, doi:10. 1890/101454.1.

Xiao, Y., Ferreira, J.G., Bricker, S.B., Nunes, J.P., Zhu, M., Zhang, X., 2007. Trophic assessment in Chinese coastal systems - Review of methodologies and application to the Changjiang (Yangtze) estuary and Jiaozhou Bay. Estuaries and Coasts 30 (6), $1 \mathrm{e} 18$.

Yunev, O.A., Carstensen, J., Moncheva, S., Khaliulin, A., Ærtebjerg, G., Nixon, S., 2007. Nutrient and phytoplankton trends on the western Black Sea shelf in response to cultural eutrophication and climate changes. Estuarine Coastal and Shelf Science $74,63 e 76$.

Zaldívar, J.M., Cardoso, A.C., Viaroli, P., Newton, A., de Wit, R., Ibañez, C., Reizopoulou, S., Somma, F., Razinkovas, A., Basset, A., Holme, M., Murray, N., 2008. Eutrophication in transitional waters: an overview. Transitional Waters Monographs 2 (1), 1 e78. 
Table 1. Definition of eutrophication, with commentary

\begin{tabular}{|c|c|}
\hline Definition & Commentary \\
\hline $\begin{array}{l}\text { Eutrophication is a } \\
\text { process driven by } \\
\text { enrichment of water } \\
\text { by nutrients, }\end{array}$ & $\begin{array}{l}\text { The process can be natural or human-driven, or both. Other human } \\
\text { pressures on the marine environment can lead to similar changes and } \\
\text { impacts, so it is a necessary condition of a diagnosis of eutrophication } \\
\text { that the changes are linked to nutrient enrichment. }\end{array}$ \\
\hline $\begin{array}{l}\text { especially compounds } \\
\text { of nitrogen and/or } \\
\text { phosphorus, }\end{array}$ & $\begin{array}{l}\text { The main compounds are those involving nitrate, ammonium and } \\
\text { phosphate, which are needed for algal growth; however, the decay of } \\
\text { organic compounds of } N \text { and } P \text { can release these inorganic nutrients; } \\
\text { and recent research has shown that organic forms such as urea can } \\
\text { contribute directly to increased growth and may favour some harmful } \\
\text { organisms. Attention should also be paid to changes in the ratios of } \\
\text { nutrient }-N \text { and }-P \text { to each other and to dissolved silica, needed by } \\
\text { diatoms }\end{array}$ \\
\hline $\begin{array}{l}\text { leading to: increased } \\
\text { growth, primary } \\
\text { production and } \\
\text { biomass of algae; }\end{array}$ & $\begin{array}{l}\text { 'Algae' is meant to refer to cyanobacterial and algal members of the } \\
\text { phytoplankton and phytobenthos, the latter including macro-algae } \\
\text { ('seaweeds'). We omit 'higher forms of plant life' in the present context } \\
\text { as seagrasses can be harmed but not stimulated by the eutrophication } \\
\text { process. We stress the centrality of 'increased primary production' to the } \\
\text { definition, but restrict this to increased autochthonous organic } \\
\text { production driven by increased allochthonous nutrient supply. }\end{array}$ \\
\hline $\begin{array}{l}\text { changes in the } \\
\text { balance of organisms; }\end{array}$ & $\begin{array}{l}\text { Such changes are likely to take place initially in the phytoplankton and } \\
\text { phytobenthos, and then propagate through marine food webs. The } \\
\text { primary producer changes, which may in part result from perturbations } \\
\text { of natural ratios of nutrient elements, include shifts from diatoms to } \\
\text { cyanobacteria or flagellates, and the suppression of fucoid seaweeds, or } \\
\text { sea-grasses, by an overgrowth of opportunistic (green or brown) algae. }\end{array}$ \\
\hline $\begin{array}{l}\text { and water quality } \\
\text { degradation. }\end{array}$ & $\begin{array}{l}\text { Such degradation includes: 'aesthetic' effects such as the appearance of } \\
\text { Red Tides or excessive foam; decreases in water transparency resulting } \\
\text { from greater biomass of phytoplankton; and decreases in bottom-water } \\
\text { or sediment pore-water oxygen content because of the decay of } \\
\text { increased primary production }\end{array}$ \\
\hline $\begin{array}{l}\text { The consequences of } \\
\text { eutrophication are } \\
\text { undesirable if they } \\
\text { appreciably degrade } \\
\text { ecosystem health }\end{array}$ & $\begin{array}{l}\text { 'Ecosystem health' refers to the homeostatic (self-regulatory) ability and } \\
\text { resilience of marine food webs interacting with their non-living } \\
\text { environment, and is evident in their 'structure' (which includes functional } \\
\text { components of biodiversity) and 'vigour' (which includes food-web } \\
\text { function and biogeochemical cycling). Note that change in the balance } \\
\text { of organisms is not in itself undesirable, and can occur naturally; we are } \\
\text { concerned with nutrient-induced changes that harm ecosystem structure } \\
\text { and function, exemplified by loss of seagrass meadows as a result of } \\
\text { decreased water transparency, or by increased mortalities of benthic } \\
\text { animals because of bottom-water deoxygenation. }\end{array}$ \\
\hline $\begin{array}{l}\text { and/or the sustainable } \\
\text { provision of goods and } \\
\text { services. }\end{array}$ & $\begin{array}{l}\text { The nutrient-driven increase in primary production that is key to } \\
\text { eutrophication can lead to increased harvest of fish or shellfish, as well } \\
\text { as to undesirable consequences, such as damage to exploited fish } \\
\text { stocks by water deoxygenation or to tourism by the accumulation of } \\
\text { algal foam on beaches. Changes in the balance of organisms might (but } \\
\text { don't always) include more frequent occurrences of toxic algae. }\end{array}$ \\
\hline
\end{tabular}


Table 2. Methods of eutrophication assessment, and examples of biological and physicochemical indicators used, and integration capabilities (pressure-state, and overall; modified from Borja et al., in press).

\begin{tabular}{|c|c|c|c|c|}
\hline Method Name & Biological indicators & $\begin{array}{l}\text { Physico-chemical } \\
\text { indicators }\end{array}$ & $\begin{array}{l}\text { Nutrient load } \\
\text { related to } \\
\text { impairments }\end{array}$ & $\begin{array}{l}\text { Integrated } \\
\text { final rating }\end{array}$ \\
\hline $\mathrm{TRIX}^{2}$ & Chl & DO, DIN, TP & no & yes \\
\hline $\begin{array}{l}\text { EPA NCA Water } \\
\text { Quality Index }{ }^{1}\end{array}$ & Chl & $\begin{array}{l}\text { Water clarity, DO, DIN, } \\
\text { DIP }\end{array}$ & no & yes \\
\hline ASSETS $^{5}$ & $\begin{array}{l}\text { Chl, macroalgae, } \\
\text { seagrass, HAB }\end{array}$ & $\mathrm{DO}$ & yes & yes \\
\hline LWQI/TWQI $^{3}$ & $\begin{array}{l}\text { Chl, macroalgae, } \\
\text { seagrass }\end{array}$ & DO, DIN, DIP & no & yes \\
\hline $\begin{array}{l}\text { OSPAR } \\
\text { COMPP }^{7}\end{array}$ & $\begin{array}{l}\text { Chl, macroalgae, } \\
\text { seagrass, } \\
\text { phytoplankton } \\
\text { indicator species }\end{array}$ & DO, TP, TN, DIN, DIP & yes & yes \\
\hline WFD $^{6}$ & $\begin{array}{l}\text { Phytoplankton, Chl, } \\
\text { macroalgae, benthic } \\
\text { invertebrates, } \\
\text { seagrass, }\end{array}$ & $\begin{array}{l}\mathrm{DO}, \mathrm{TP}, \mathrm{TN}, \mathrm{DIN}, \mathrm{DIP}, \\
\text { water clarity }\end{array}$ & no & yes \\
\hline HEAT $^{4}$ & $\begin{array}{l}\text { Chl, primary } \\
\text { production, seagrass, } \\
\text { benthic invertebrates, } \\
\text { HAB, macroalgae }\end{array}$ & $\begin{array}{l}\text { DIN, DIP, TN, TP, DO, } \\
\text { C, water clarity }\end{array}$ & no & yes \\
\hline IFREMER $^{8}$ & $\begin{array}{l}\text { Chl, seagrass, } \\
\text { macrobenthos, HAB }\end{array}$ & $\begin{array}{l}\text { DO water clarity, SRP, } \\
\text { TP, TN, DIN, sediment } \\
\text { organic matter, } \\
\text { sediment TN, TP }\end{array}$ & no & yes \\
\hline $\mathrm{STI}^{9}$ & $\begin{array}{l}\text { Chl, Primary } \\
\text { Production }\end{array}$ & DIN, DIP & no & no \\
\hline
\end{tabular}

${ }^{1}$ USEPA, 2005, 2008. ${ }^{2}$ Vollenweider et al., 1998; ${ }^{3}$ Giordani et al., 2009; ${ }^{4}$ Andersen and Laamanen, 2009; ${ }^{5}$ Bricker et al., 1999, 2003, 2007; ${ }^{6}$ Devlin et al., in prep; ${ }^{7}$ OSPAR, 2002, 2008;

${ }^{8}$ Souchu et al., 2000; ${ }^{9}$ Ignatiades, 2005. 
Table 3. Pressures and impacts to be considered for the eutrophication Quality Descriptor, as defined in Tables 1 and 2 of Annex III of the MSFD.

\begin{tabular}{|c|c|c|c|c|}
\hline & Characteristics & & Pressures and impacts \\
\hline 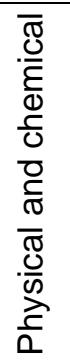 & 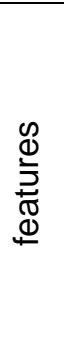 & $\begin{array}{l}\text { Spatial and temporal distribution of } \\
\text { nutrients (DIN, TN, DIP, TP, TOC) } \\
\text { and oxygen, pH, pCO2 profiles or } \\
\text { equivalent information used to } \\
\text { measure marine acidification }^{1}\end{array}$ & $\begin{array}{l}\text { Nutrient and } \\
\text { organic } \\
\text { matter } \\
\text { enrichment }\end{array}$ & $\begin{array}{l}\text { Inputs of fertilizers and other } \\
\text { nitrogen and phosphorus-rich } \\
\text { substances (e.g. from point } \\
\text { and diffuse sources, including } \\
\text { agriculture, aquaculture, } \\
\text { atmospheric deposition), } \\
\text { Inputs of organic matter (e.g. } \\
\text { sewers, mariculture, riverine } \\
\text { inputs) }\end{array}$ \\
\hline \multirow{2}{*}{\multicolumn{2}{|c|}{ 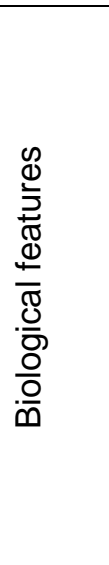 }} & $\begin{array}{l}\text { A description of the biological } \\
\text { communities associated with the } \\
\text { predominant seabed and water } \\
\text { column habitats. This would include } \\
\text { information on the phytoplankton and } \\
\text { zooplankton communities, including } \\
\text { the species and seasonal and } \\
\text { geographical variability }\end{array}$ & $\begin{array}{l}\text { Nutrient and } \\
\text { organic } \\
\text { matter } \\
\text { enrichment }\end{array}$ & Changes in production \\
\hline & & $\begin{array}{l}\text { Information on angiosperms, macro- } \\
\text { algae and invertebrate bottom fauna, } \\
\text { including species composition, } \\
\text { biomass and annual/seasonal } \\
\text { variability }\end{array}$ & $\begin{array}{l}\text { Nutrient and } \\
\text { organic } \\
\text { matter } \\
\text { enrichment } \\
\text { Physical } \\
\text { alteration }\end{array}$ & $\begin{array}{l}\text { Changes in production, } \\
\text { changes in spatial coverage of } \\
\text { bottom flora and fauna }\end{array}$ \\
\hline
\end{tabular}

\footnotetext{
${ }^{1}$ Under the slightly more alkaline conditions associated with eutrophication a reduction in pCO2 and increase in $\mathrm{pH}$ would be expected.
} 
Table 4. Methods to evaluate the status of phytoplankton in coastal and estuarine water bodies (modified from Borja et al., in press). References: 1EPA (Environment Protection Agency) (USEPA, 2005, 2008). 2Vollenweider et al., 1998. 3TWQI/LWQI (Transitional Water Quality Index) Giordani et al., 2009. ${ }^{4} \mathrm{HELCOM}$, 2009. ${ }^{5}$ Bricker et al., 2003, 2007. ${ }^{6}$ WFD (Water Framework Directive) XXX ${ }^{7}$ European Commission, 2008; ${ }^{8}$ OSPAR COMPP (OSPAR Comprehensive Procedure) OSPAR, 2002, 2008. ${ }^{9}$ Souchu et al., 2000.

\begin{tabular}{|c|c|c|c|c|c|c|c|c|}
\hline \multirow{2}{*}{ Method } & \multirow{2}{*}{$\begin{array}{l}\text { Area using } \\
\text { method }\end{array}$} & \multicolumn{4}{|l|}{ Biomass } & \multirow{2}{*}{$\begin{array}{l}\text { Community } \\
\text { composition }\end{array}$} & \multirow{2}{*}{ 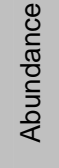 } & \multirow{2}{*}{$\begin{array}{l}\text { Indicators in Overall } \\
\text { Eutrophication Index }\end{array}$} \\
\hline & & $\begin{array}{l}\text { Chl a Thresholds and Ranges } \\
\left(\text { ug l}^{-1}\right)\end{array}$ & $\begin{array}{l}\text { Sample } \\
\text { Timeframe }\end{array}$ & Statistical measure & $\begin{array}{c}\text { Other } \\
\text { characteristics }\end{array}$ & & & \\
\hline EPA NCA ${ }^{1}$ & US & $\begin{array}{l}\text { Poor > 20; Fair 5-20, Good 0- } \\
5 \text {; lower for sensitive systems }\end{array}$ & $\begin{array}{l}\text { Index period } \\
\text { (June - Oct) }\end{array}$ & $\begin{array}{l}\text { concentration, } \% \text { of coastal } \\
\text { area in poor, fair and good } \\
\text { condition based on } \\
\text { probabilistic sampling } \\
\text { design for } 90 \% \text { confidence } \\
\text { in areal result }\end{array}$ & & \multicolumn{2}{|l|}{ No } & $\begin{array}{l}\text { Chl a, water clarity, DO, } \\
\text { DIP, DIN }\end{array}$ \\
\hline $\mathrm{TRIX}^{2}$ & $\mathrm{EU}$ & $\begin{array}{l}\text { no thresholds, integrated with } \\
\text { other index variables }\end{array}$ & & concentration & & \multicolumn{2}{|l|}{ No } & Chl a, DO, DIN, TP \\
\hline $\begin{array}{l}\text { TWQI } \\
\text { /LWQI }^{3}\end{array}$ & EU & $\begin{array}{l}\text { Good QV100 = 6; Bad QV0 = } \\
30\end{array}$ & annual & $\begin{array}{l}\text { Chl concentration mean } \\
\text { annual or seasonal } \\
\text { modified by weighting factor }\end{array}$ & & \multicolumn{2}{|l|}{ No } & $\begin{array}{l}\text { Chl a, seagrasses, } \\
\text { macroalgae, DO, DIN, DIP }\end{array}$ \\
\hline HEAT $^{4}$ & Baltic & $\begin{array}{l}\text { Deviation from ref } E Q R<0.67 ; \\
\text { No dev from ref } E Q R>0.67\end{array}$ & $\begin{array}{l}\text { summer } \\
\text { (June - Sept) }\end{array}$ & $\begin{array}{l}\text { mean summer } \\
\text { concentration }\end{array}$ & $\begin{array}{l}\text { increases in } \\
\text { concentration, } \\
\text { frequency and } \\
\text { duration }\end{array}$ & indicator spp & $x$ & $\begin{array}{l}\text { Chl a, phytoplankton, } \\
\text { nutrients, water } \\
\text { transparency, SAV, DO, } \\
\text { benthic invertebrates, } \\
\text { summertime bloom intensity } \\
\text { index }\end{array}$ \\
\hline ASSETS $^{5}$ & $\begin{array}{l}\text { US, EU, } \\
\text { Asia, } \\
\text { Australia }\end{array}$ & $\begin{array}{l}\text { High >20; Mod 5-20; Low 0-5; } \\
\text { lower for sensitive systems }\end{array}$ & annual & $\begin{array}{l}\text { 90th percentile Chl } \\
\text { concentration of annual data }\end{array}$ & $\begin{array}{l}\text { spatial coverage, } \\
\text { frequency } \\
\text { occurrence }\end{array}$ & \multicolumn{2}{|l|}{$\begin{array}{l}\text { Nuisance and } \\
\text { toxic bloom } \\
\text { occurrence, } \\
\text { frequency, } \\
\text { duration }\end{array}$} & $\begin{array}{l}\text { Chl a, macroalgae, DO, } \\
\text { seagrasses, nuisance/toxic } \\
\text { blooms }\end{array}$ \\
\hline WFD $^{6}$ & $\begin{array}{l}\text { Basque } \\
\text { Country }\end{array}$ & $\begin{array}{l}\text { Cantabrian coast: Bad }>14 \text {, } \\
\text { Poor } 10.5-14 \text {, Moderate } 7- \\
\text { 10.5, Good 3.5-7, High } 0-3.5\end{array}$ & summer & $\begin{array}{l}\text { summer Chl concentration } \\
\text { mean, max and sometimes } \\
\text { 90th percentile annual data }\end{array}$ & $\begin{array}{l}\text { increases in } \\
\text { concentration, } \\
\text { frequency and } \\
\text { duration }\end{array}$ & indicator spp & $x$ & $\begin{array}{l}\text { Chl a, phytoplankton, } \\
\text { macroalgae, } \\
\text { microphytobenthos, } \\
\text { seagrasses, DO, nutrients, } \\
\text { algal toxins }\end{array}$ \\
\hline
\end{tabular}




\begin{tabular}{|c|c|c|c|c|c|c|c|c|}
\hline WFD $^{7}$ & UK & $\begin{array}{l}\text { Mediterranean coast }\left(\mathrm{PgO}^{\text {th }}\right) \text { : } \\
\text { T2 }(34.5<\mathrm{sal}<37.5) \\
\text { A: } \mathrm{H} / \mathrm{G}=2.4(\mathrm{EQR}=0.80) ; \mathrm{G} / \mathrm{M} \\
\text { 3.6 }(\mathrm{EQR}=0.53) \\
\text { T3 (sal>37.5) W-Med: } \mathrm{H} / \mathrm{G}=1.1 \\
(\mathrm{EQR}=0.80) ; \mathrm{G} / \mathrm{M} 1.8 \\
(\mathrm{EQR}=0.50) . \\
\mathrm{E}-\mathrm{Med}: \mathrm{H} / \mathrm{G}=0.1(\mathrm{EQR}=0.80) \text {, } \\
\text { G/M 0.4 (EQR=0.20) }\end{array}$ & $\begin{array}{l}\text { At least } 5 \text { years } \\
\text { data available, } \\
\text { with monthly } \\
\text { sampling, in the } \\
\text { surface layer }\end{array}$ & $\begin{array}{l}\text { EQR based on Chl } \\
\text { concentration mean or 90th } \\
\text { percentile }\end{array}$ & $\begin{array}{l}\text { Mean salinity or } \\
\text { density }\end{array}$ & No & No & $\begin{array}{l}\text { Biological quality elements } \\
\text { (phytoplankton, } \\
\text { macroalgae, } \\
\text { macroinvertebrates, } \\
\text { seagrasses) }\end{array}$ \\
\hline $\begin{array}{l}\text { OSPAR } \\
\text { COMPP }^{8}\end{array}$ & $\begin{array}{l}\text { North East } \\
\text { Atlantic }\end{array}$ & $\begin{array}{l}\text { NPA if below } R C+50 \% \text {, } \\
\text { PA if above } R C+50 \%\end{array}$ & growing season & $\begin{array}{l}\text { growing season Chl } \\
\text { concentration mean, max }\end{array}$ & $\begin{array}{l}\text { increases in } \\
\text { concentration, } \\
\text { frequency and } \\
\text { duration }\end{array}$ & indicator spp & $x$ & $\begin{array}{l}\text { Chl a, phytoplankton, } \\
\text { macroalgae, } \\
\text { microphytobenthos, } \\
\text { seagrasses, DO, nutrients, } \\
\text { algal toxins }\end{array}$ \\
\hline $\begin{array}{l}\text { IFREMER }^{9} \\
\text { (lagoons) }\end{array}$ & France & $\begin{array}{l}\text { > } 30 \text { Red; } 10-30 \text { Orange; } \\
\text { 7-10 Yellow; 5-7 Green; 0-5 } \\
\text { Blue }\end{array}$ & annual & $\begin{array}{l}\text { mean annual Chl } \\
\text { concentration }\end{array}$ & & $\begin{array}{l}\text { phytoplankton } \\
\text { abundance of } \\
<2 \mathrm{~m},>2 \mathrm{~m}\end{array}$ & $x$ & $\begin{array}{l}\text { Chl a, phytoplankton counts } \\
(<2,>2 \mathrm{~m} \text { ), macrophytes } \\
\text { (biomass, diversity), } \\
\text { macrobenthos (richness, } \\
\text { diversity), water (DO, Chl, } \\
\text { Chl/phaeo, turbidity, SRP, } \\
\left.\text { TP, TN, } \mathrm{NO}_{2}, \mathrm{NO}_{3}, \mathrm{NH}_{4}\right) \\
\text { sediment }(\mathrm{OM}, \mathrm{TN}, \mathrm{TP})\end{array}$ \\
\hline
\end{tabular}


Table 5. Tentative list of eutrophication indicators and timeframes for marine waters assuming samples are taken on a spatially representative basis (see Table 4 for alternative approaches).

\begin{tabular}{|c|c|c|c|}
\hline $\begin{array}{l}\text { Indicator } \\
\text { Type }\end{array}$ & Indicator & Sampling timeframe $^{1}$ & Statistics \\
\hline 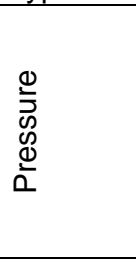 & $\begin{array}{l}\text { Nutrient load } \\
\text { (Nitrogen, } \\
\text { Phosphorus) }\end{array}$ & $\begin{array}{l}\text { Annual estimate to match } \\
\text { timeframe of eutrophication } \\
\text { condition assessment }\end{array}$ & $\begin{array}{l}\text { Tons/year can be calculated from } \\
\text { riverine and direct inputs adjusted to } \\
\text { the inflow, industrial and urban water } \\
\text { treatment plant loads. OSPAR RID } \\
\text { Programme and HELCOM Pollution } \\
\text { Load Compilations (PLCs) could be } \\
\text { used for guidance. }\end{array}$ \\
\hline \multirow{9}{*}{ 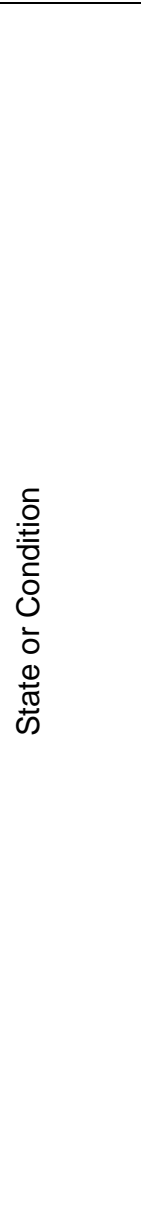 } & $\begin{array}{l}\text { Increase in } \\
\text { primary } \\
\text { production }\end{array}$ & $\begin{array}{l}\text { Estimates at some periodicity over } \\
\text { the annual cycle }\end{array}$ & $\begin{array}{l}\text { Can use chlorophyll and other algal } \\
\text { components as a proxy or use remote } \\
\text { sensing plus modelling as appropriate } \\
\text { and as resources allow }\end{array}$ \\
\hline & Chlorophyll & $\begin{array}{l}\text { Monthly, or more frequent as } \\
\text { appropriate and as possible } \\
\text { especially for dynamic areas }\end{array}$ & $\begin{array}{l}90^{\text {th }} \text { percentile concentration, spatial } \\
\text { area of high concentrations }\end{array}$ \\
\hline & $\begin{array}{l}\text { Dissolved } \\
\text { Oxygen }\end{array}$ & $\begin{array}{l}\text { Monthly, or more frequent as } \\
\text { appropriate and as possible } \\
\text { especially for dynamic areas }\end{array}$ & $\begin{array}{l}10^{\text {th }} \text { percentile concentration, spatial } \\
\text { area of low concentrations }\end{array}$ \\
\hline & $\begin{array}{l}\text { Opportunistic } \\
\text { macroalgae }\end{array}$ & $\begin{array}{l}\text { Annual sampling in spring - } \\
\text { summer when blooms are more } \\
\text { probable }\end{array}$ & $\begin{array}{l}\text { Blooms that cause detriment to living } \\
\text { resources, duration of blooms, } \\
\text { approximate spatial coverage of } \\
\text { blooms }\end{array}$ \\
\hline & $\begin{array}{l}\text { Nuisance/toxic } \\
\text { algal blooms }\end{array}$ & $\begin{array}{l}\text { Annual Bloom events } \\
\text { Annual to multi-year changes in } \\
\text { frequency and/or duration of } \\
\text { blooms }\end{array}$ & $\begin{array}{l}\text { Blooms that cause detriment to living } \\
\text { resources }\end{array}$ \\
\hline & $\begin{array}{l}\text { Changes in algal } \\
\text { community } \\
\text { structure }\end{array}$ & $\begin{array}{l}\text { Annual to multi-year changes from } \\
\text { fucoids/kelp to opportunistic } \\
\text { green/brown algae and/or } \\
\text { changes in balance of } \\
\text { diatoms/flagellates/cyanobacteria }\end{array}$ & $\begin{array}{l}\text { Change from diverse natural } \\
\text { community to one dominated by } \\
\text { opportunistic and/or nuisance and/or } \\
\text { toxic species }\end{array}$ \\
\hline & $\begin{array}{l}\text { Submerged } \\
\text { Aquatic } \\
\text { Vegetation }\end{array}$ & Annual surveys & $\begin{array}{l}\text { Changes in: spatial coverage, density } \\
\text { of beds }\end{array}$ \\
\hline & Benthos & Annual & $\begin{array}{l}\text { Changes in diversity and proportion } \\
\text { of sensitive vs non-sensitive spp }\end{array}$ \\
\hline & $\begin{array}{l}\text { Nutrient } \\
\text { concentrations }\end{array}$ & $\begin{array}{l}\text { Monthly or fortnightly, or more } \\
\text { frequent as appropriate and as } \\
\text { possible especially for dynamic } \\
\text { areas }\end{array}$ & $\begin{array}{l}\text { Annual means or maxima, Seasonal } \\
\text { means or maxima, others as } \\
\text { appropriate }\end{array}$ \\
\hline Other & Benthos/fish & $\begin{array}{l}\text { Observations/irregular - take note } \\
\text { of kills }\end{array}$ & Massive mortality, benthos/fish kills \\
\hline
\end{tabular}




\section{Figures}

Fig. 1. Spatial scope of the Marine Strategy Framework Directive, showing maritime boundaries for EU Member States (source: JRC).

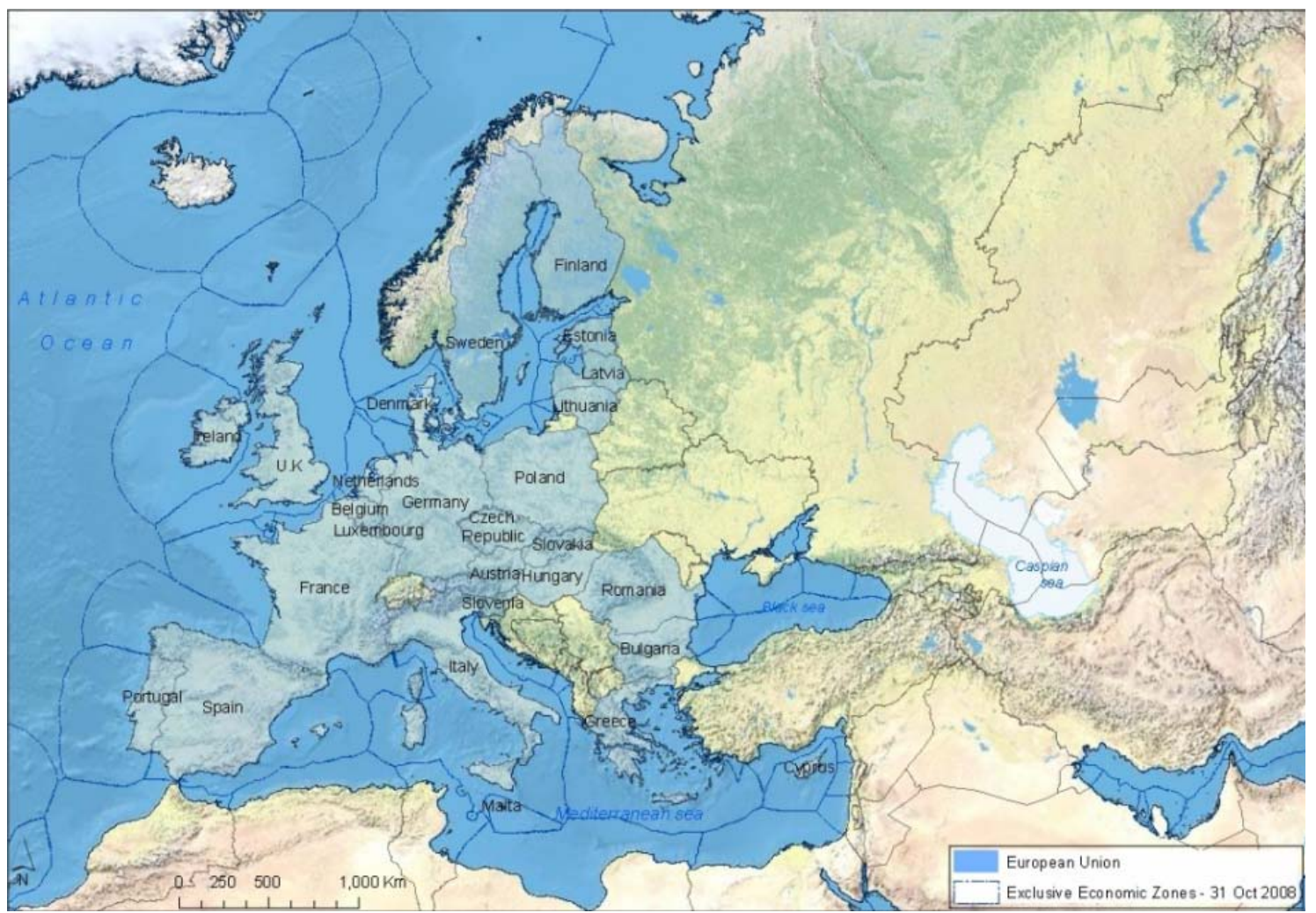


Fig. 2. Conceptual model of eutrophication. The arrows indicate the interactions between different ecological compartments. A balanced marine ecosystem is characterised by: (1) a pelagic food chain (phytoplankton -zooplankton/zoobenthos fish), which effectively couples production to consumption and minimises the potential for excess decomposition (2) natural species composition of plankton and benthic organisms, and (3) if appropriate, a natural distribution of submerged aquatic vegetation. Nutrient enrichment results in changes in the structure and function of marine ecosystems, as indicated with bold lines. Dashed lines indicate the release of hydrogen sulphide $\left(\mathrm{H}_{2} \mathrm{~S}\right)$ and phosphorus, under anoxic conditions at the sediment-water interface, which is positively related to oxygen depletion. In addition, nitrogen is eliminated by denitrification in anoxic sediment. (adapted from: HELCOM 2010).

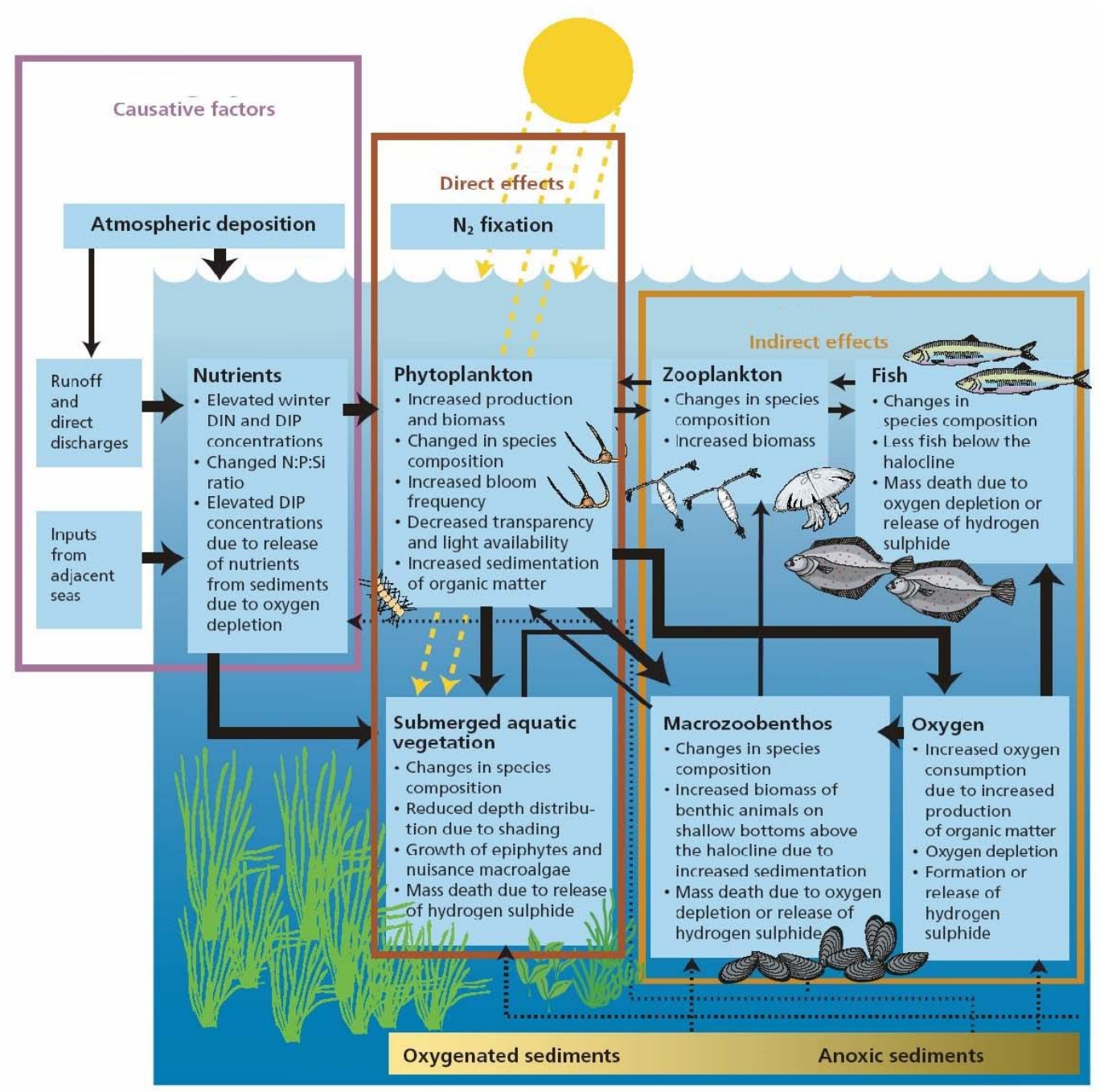

